\title{
LEVEL II SCOUR ANALYSIS FOR BRIDGE 29 (LONDTH00410029) on TOWN HIGHWAY 41, crossing COOK BROOK, LONDONDERRY, VERMONT
}

U.S. Geological Survey Open-File Report 97-403

Prepared in cooperation with

VERMONT AGENCY OF TRANSPORTATION and

FEDERAL HIGHWAY ADMINISTRATION 


\section{LEVEL II SCOUR ANALYSIS FOR BRIDGE 29 (LONDTH00410029) on TOWN HIGHWAY 41, crossing COOK BROOK, LONDONDERRY, VERMONT \\ By LORA K. STRIKER AND EMILY C. WILD}

U.S. Geological Survey Open-File Report 97-403

Prepared in cooperation with

VERMONT AGENCY OF TRANSPORTATION

and

FEDERAL HIGHWAY ADMINISTRATION 


\title{
U.S. DEPARTMENT OF THE INTERIOR BRUCE BABBITT, Secretary
}

\author{
U.S. GEOLOGICAL SURVEY \\ Gordon P. Eaton, Director
}

For additional information write to:

District Chief

U.S. Geological Survey 361 Commerce Way

Pembroke, NH 03275-3718
Copies of this report may be purchased from:

U.S. Geological Survey

Branch of Information Services

Open-File Reports Unit

Box 25286

Denver, CO 80225-0286 


\section{CONTENTS}

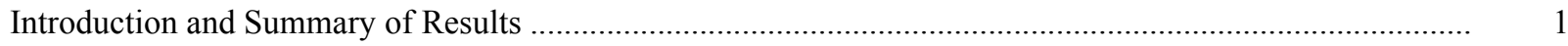

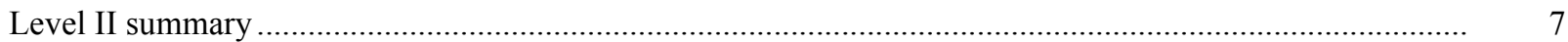

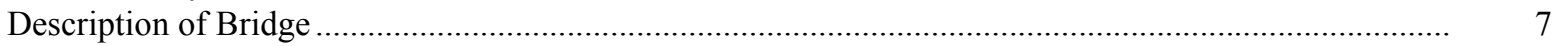

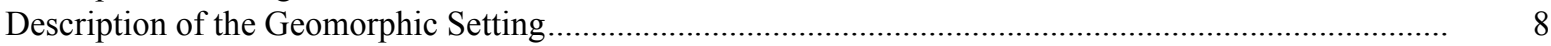

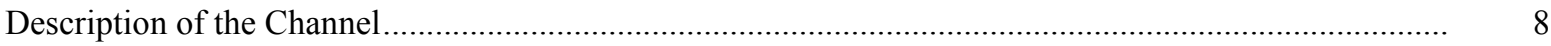

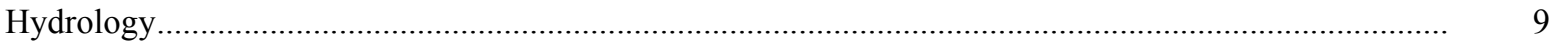

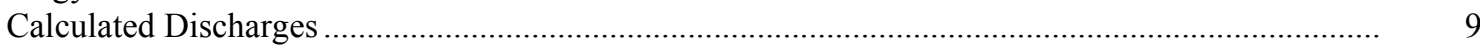

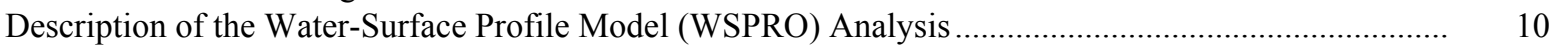

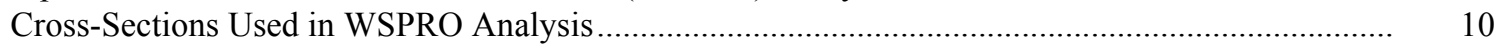

Data and Assumptions Used in WSPRO Model ...................................................................... 11

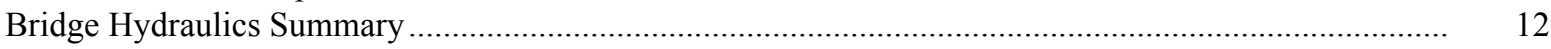

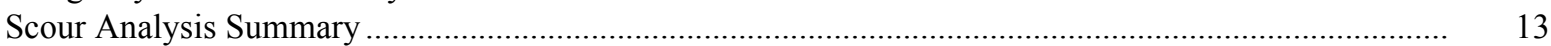

Special Conditions or Assumptions Made in Scour Analysis ...................................................... 13

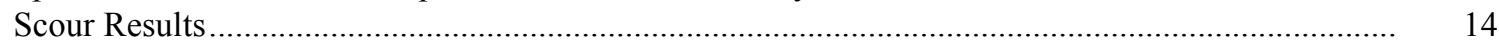

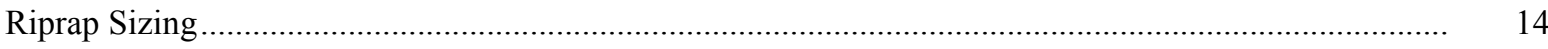

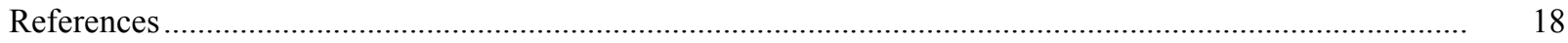

Appendixes:

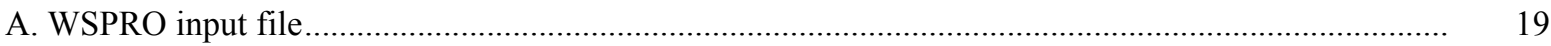

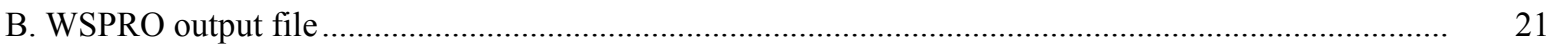

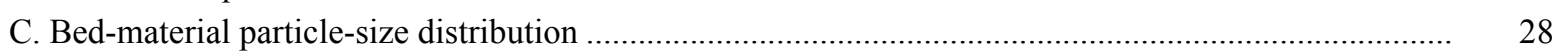

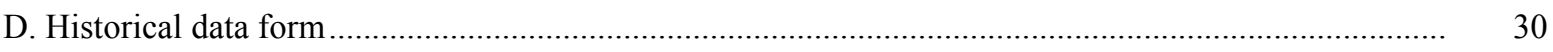

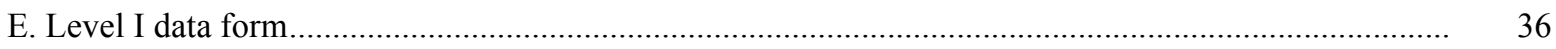

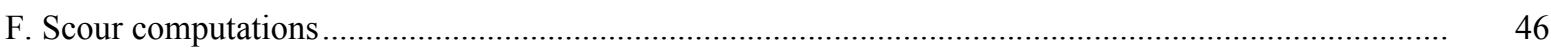

\section{FIGURES}

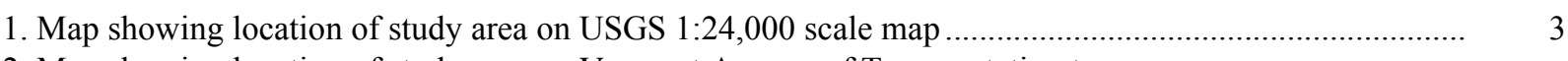

2. Map showing location of study area on Vermont Agency of Transportation town
highway map

3. Structure LONDTH00410029 viewed from upstream (August 7, 1996) ............................................... 5

4. Downstream channel viewed from structure LONDTH00410029 (August 7, 1996)............................ 5

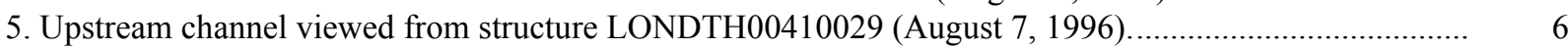

6. Structure LONDTH00410029 viewed from downstream (August 7, 1996). ........................................ 6

7. Water-surface profiles for the 100- and 500-year discharges at structure

LONDTH00410029 on Town Highway 41, crossing Cook Brook,

Londonderry, Vermont.

8. Scour elevations for the 100- and 500-year discharges at structure

LONDTH00410029 on Town Highway 41, crossing Cook Brook,

Londonderry, Vermont.

\section{TABLES}

1. Remaining footing/pile depth at abutments for the 100-year discharge at structure

LONDTH00410029 on Town Highway 41, crossing Cook Brook,

Londonderry, Vermont

2. Remaining footing/pile depth at abutments for the 500-year discharge at structure

LONDTH00410029 on Town Highway 41, crossing Cook Brook,

Londonderry, Vermont.

5
(5 


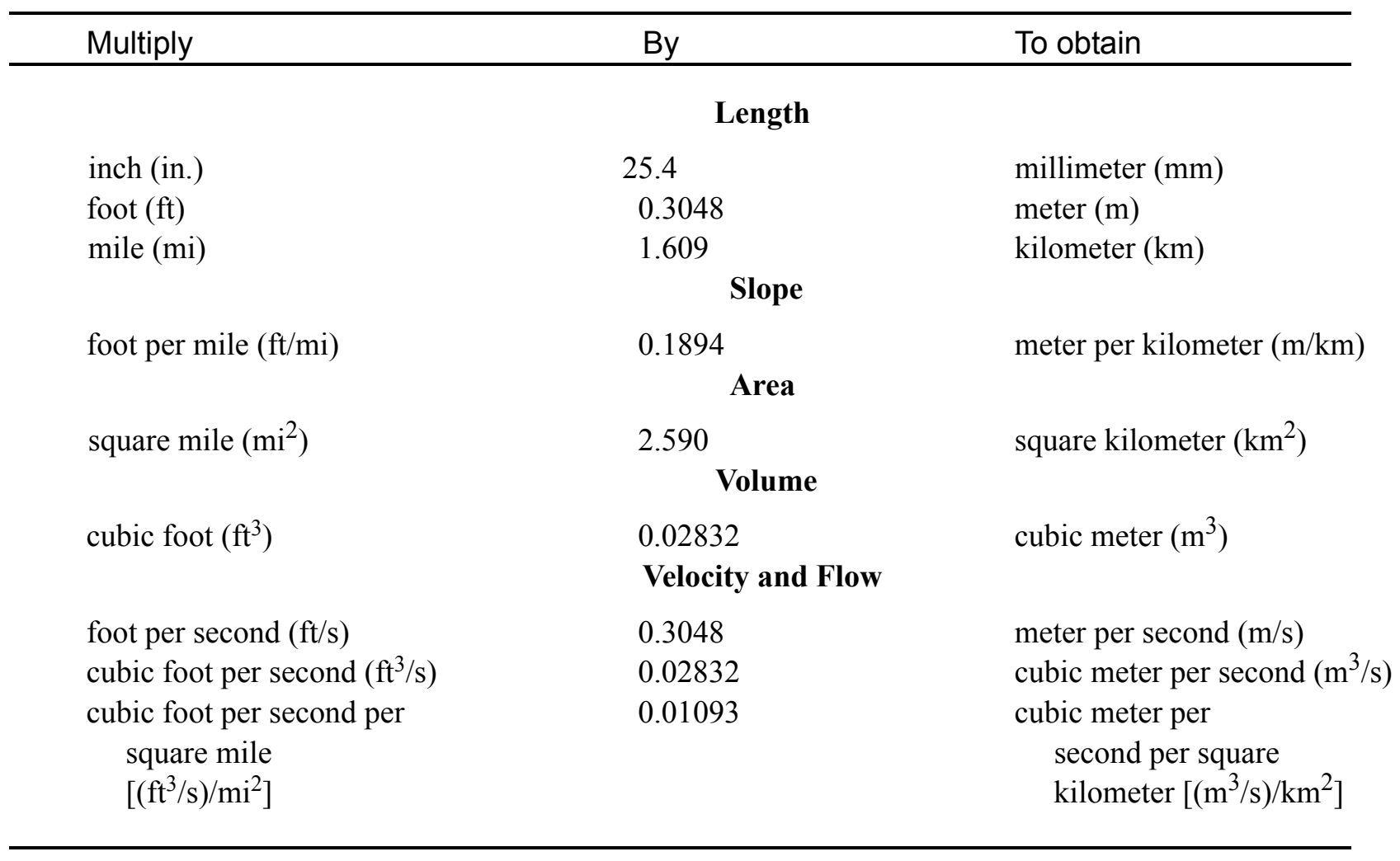

\section{OTHER ABBREVIATIONS}

$\begin{array}{lrlr}\mathrm{BF} & \text { bank full } & \text { LWW } & \text { left wingwall } \\ \mathrm{cfs} & \text { cubic feet per second } & \text { MC } & \text { main channel } \\ \mathrm{D}_{50} & \text { median diameter of bed material } & \text { RAB } & \text { right abutment } \\ \mathrm{DS} & \text { downstream } & \text { RABUT } & \text { face of right abutment } \\ \mathrm{elev} & \text { elevation } & \text { RB } & \text { right bank } \\ \mathrm{f} / \mathrm{p} & \text { flood plain } & \text { ROB } & \text { right overbank } \\ \mathrm{ft}^{2} & \text { square feet } & \text { RWW } & \text { right wingwall } \\ \mathrm{ft} / \mathrm{ft} & \text { feet per foot } & \text { TH } & \text { town highway } \\ \mathrm{JCT} & \text { junction } & \text { UB } & \text { under bridge } \\ \mathrm{LAB} & \text { left abutment } & \text { US } & \text { upstream } \\ \mathrm{LABUT} & \text { face of left abutment } & \text { USGS } & \text { United States Geological Survey } \\ \mathrm{LB} & \text { left bank } & \text { VTAOT Vermont Agency of Transportation } \\ \mathrm{LOB} & \text { left overbank } & \text { WSPRO } & \text { water-surface profile model }\end{array}$

In this report, the words "right" and "left" refer to directions that would be reported by an observer facing downstream. Sea level: In this report, "sea level" refers to the National Geodetic Vertical Datum of 1929-- a geodetic datum derived from a general adjustment of the first-order level nets of the United States and Canada, formerly called Sea Level Datum of 1929.

In the appendices, the above abbreviations may be combined. For example, USLB would represent upstream left bank. 


\title{
LEVEL II SCOUR ANALYSIS FOR BRIDGE 29 (LONDTH00410029) ON TOWN HIGHWAY 41, CROSSING COOK BROOK, LONDONDERRY, VERMONT
}

\author{
By Lora K. Striker and Emily C. Wild
}

\section{INTRODUCTION AND SUMMARY OF RESULTS}

This report provides the results of a detailed Level II analysis of scour potential at structure LONDTH00410029 on Town Highway 41 crossing Cook Brook, Londonderry, Vermont (figures 1-8). A Level II study is a basic engineering analysis of the site, including a quantitative analysis of stream stability and scour (U.S. Department of Transportation, 1993). Results of a Level I scour investigation also are included in Appendix E of this report. A Level I investigation provides a qualitative geomorphic characterization of the study site. Information on the bridge, gleaned from Vermont Agency of Transportation (VTAOT) files, was compiled prior to conducting Level I and Level II analyses and is found in Appendix D.

The site is in the Green Mountain section of the New England physiographic province in south-central Vermont. The $6.48-\mathrm{mi}^{2}$ drainage area is in a predominantly rural and forested basin. In the vicinity of the study site, the surface cover is shrub on the left bank upstream and downstream of the bridge while the right bank is forest upstream and downstream of the bridge.

In the study area, Cook Brook has a straight incised channel with a slope of approximately $0.02 \mathrm{ft} / \mathrm{ft}$, an average channel top width of $80 \mathrm{ft}$ and an average bank height of $8 \mathrm{ft}$. The channel bed material ranges from sand to cobble with a median grain size $\left(D_{50}\right)$ of $70.9 \mathrm{~mm}$ $(0.233 \mathrm{ft})$. The geomorphic assessment at the time of the Level I and Level II site visit on August 7, 1996, indicated that the reach was stable.

The Town Highway 41 crossing of Cook Brook is a 25-ft-long, one-lane bridge consisting of one 22-foot steel-beam span (Vermont Agency of Transportation, written communication, April 6, 1995). The opening length of the structure parallel to the bridge face is $20.4 \mathrm{ft}$. The bridge is supported by vertical, concrete abutments with wingwalls. The channel is skewed approximately 5 degrees to the opening while the opening-skew-toroadway is 0 degrees. 
A scour hole $1.0 \mathrm{ft}$ deeper than the mean thalweg depth was observed along the upstream left wingwall and left abutment during the Level I assessment. The only scour protection measure at the site was type- 2 stone fill (less than 36 inches) along the downstream end of the left abutment and upstream end of the downstream right wingwall. Additional details describing conditions at the site are included in the Level II Summary and Appendices D and E.

Scour depths and recommended rock rip-rap sizes were computed using the general guidelines described in Hydraulic Engineering Circular 18 (Richardson and others, 1995). Total scour at a highway crossing is comprised of three components: 1) long-term streambed degradation; 2) contraction scour (due to accelerated flow caused by a reduction in flow area at a bridge) and; 3 ) local scour (caused by accelerated flow around piers and abutments). Total scour is the sum of the three components. Equations are available to compute depths for contraction and local scour and a summary of the results of these computations follows.

Contraction scour for all modelled flows ranged from 0.0 to 1.5. Abutment scour ranged from 8.4 to $15.1 \mathrm{ft}$. The worst-case abutment scour occurred at the 500-year discharge. Additional information on scour depths and depths to armoring are included in the section titled "Scour Results". Scoured-streambed elevations, based on the calculated scour depths, are presented in tables 1 and 2. A cross-section of the scour computed at the bridge is presented in figure 8 . Scour depths were calculated assuming an infinite depth of erosive material and a homogeneous particle-size distribution.

It is generally accepted that the Froehlich equation (abutment scour) gives "excessively conservative estimates of scour depths" (Richardson and others, 1995, p. 47). Usually, computed scour depths are evaluated in combination with other information including (but not limited to) historical performance during flood events, the geomorphic stability assessment, existing scour protection measures, and the results of the hydraulic analyses. Therefore, scour depths adopted by VTAOT may differ from the computed values documented herein. 


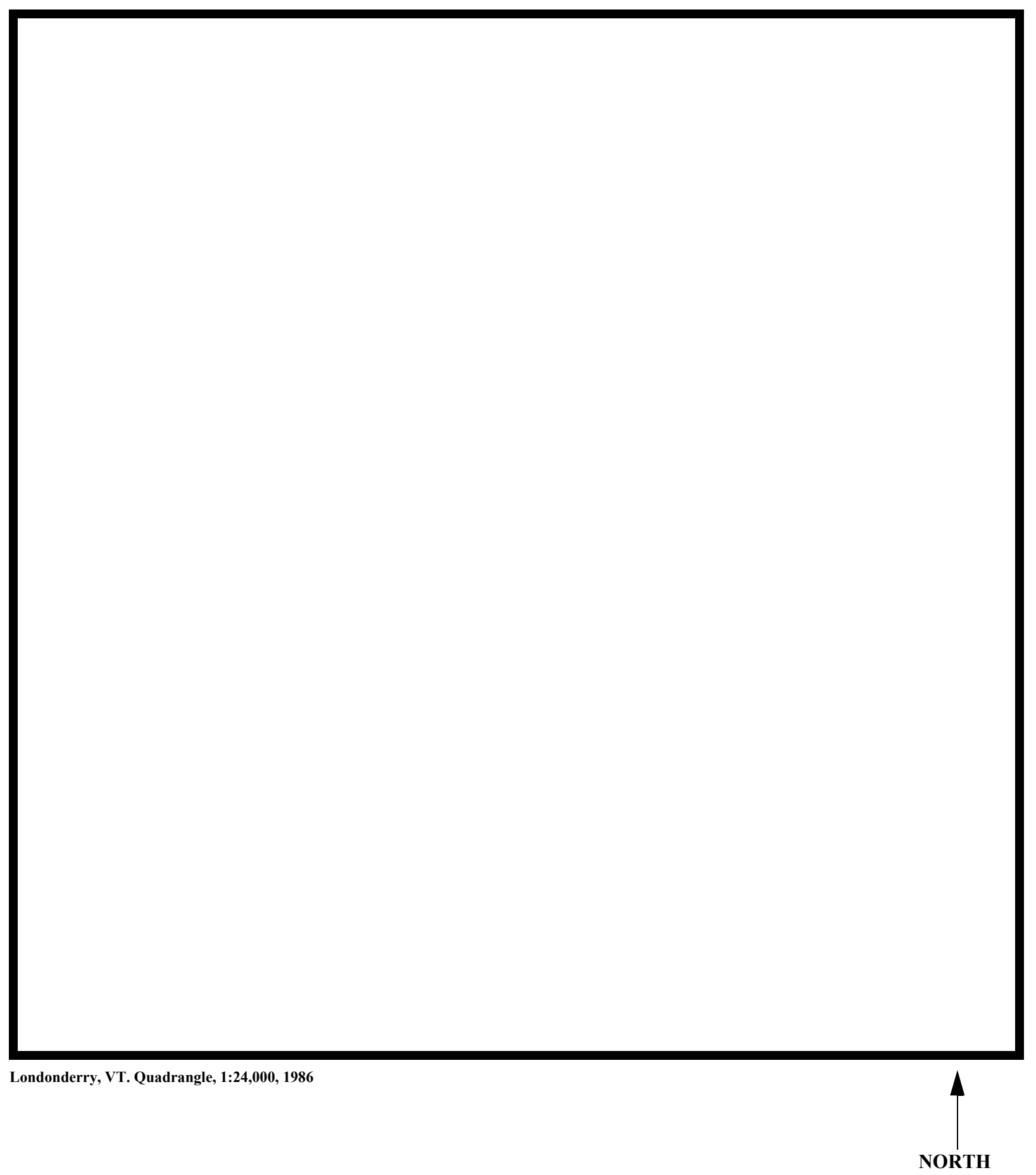

Figure 1. Location of study area on USGS 1:24,000 scale map. 
Figure 2. Location of study area on Vermont Agency of Transportation town highway map. 

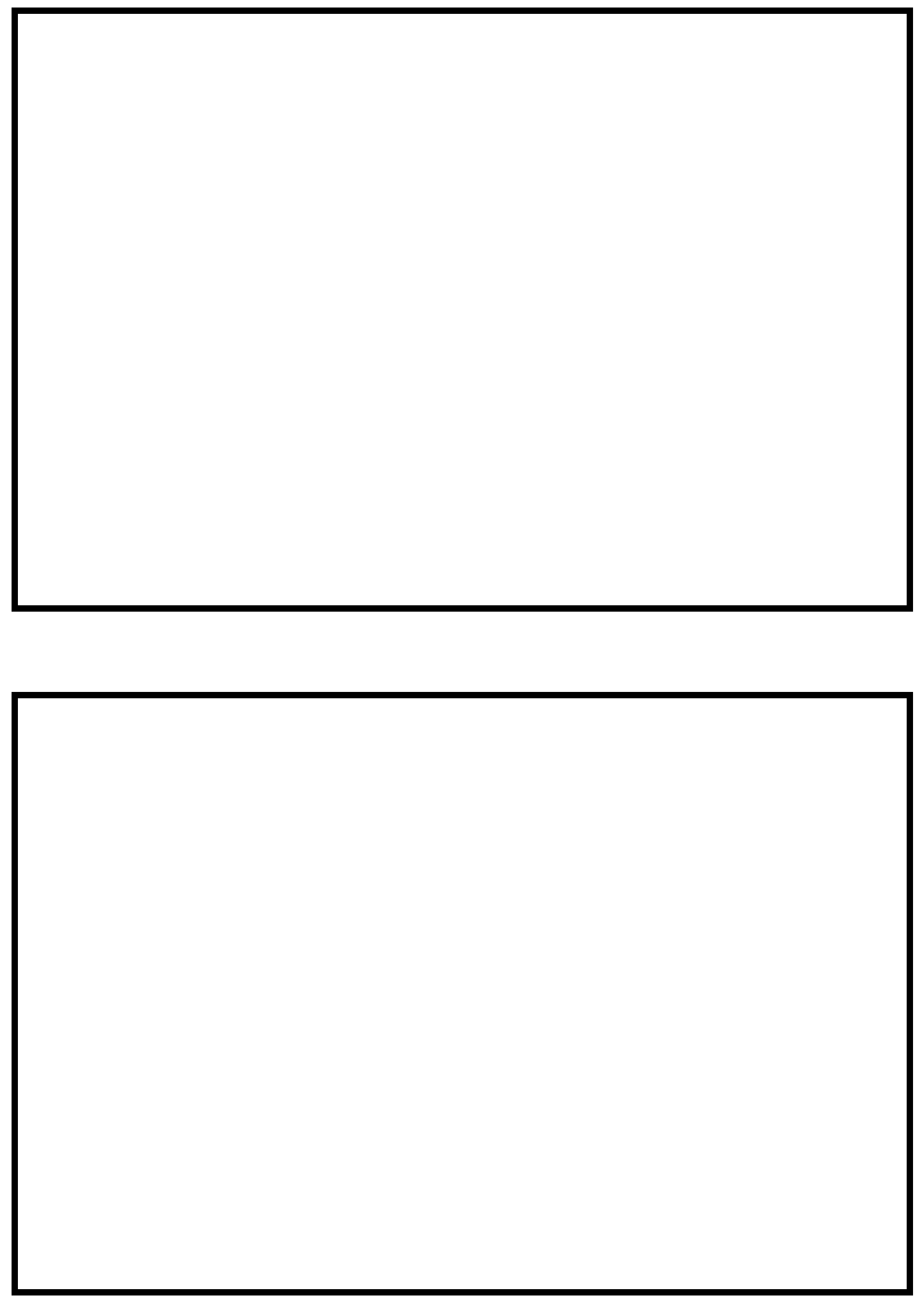

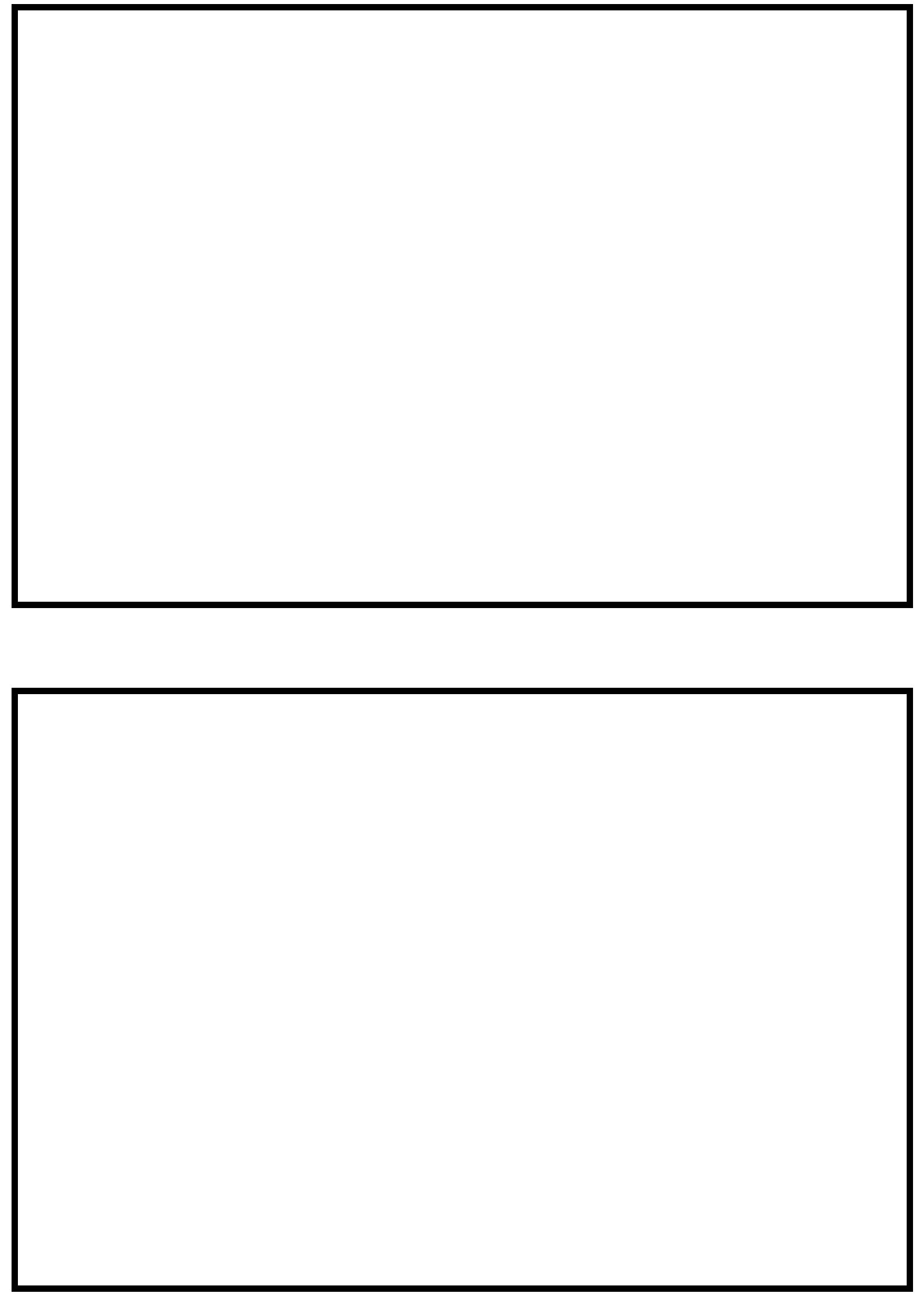


\section{Description of the Geomorphic Setting}

General topography The channel is located within a moderate relief valley.

Geomorphic conditions at bridge site: downstream (DS), upstream (US)

Date of inspection $\quad 08 / 07 / 96$

DS left: $\quad$ Steep channel bank to moderately sloped overbank

DS right: $\quad$ Moderately sloped overbank

US left: $\quad$ Steep channel bank to moderately sloped overbank

US right: $\quad$ Moderately sloped overbank

\section{Description of the Channel}

\begin{tabular}{|c|c|c|c|}
\hline \multirow[b]{2}{*}{ Average top width } & & \multirow[b]{2}{*}{ Average depth } & \multirow[b]{2}{*}{ Sand/Gravel ${ }^{\boldsymbol{f t}}$} \\
\hline & Sand / Gravel & & \\
\hline Predominant bed material & & Bank material & Straight and stable \\
\hline with semi-alluvial boundaries. & $\cdots \cdot$ & ". $\cdot$ & \\
\hline
\end{tabular}

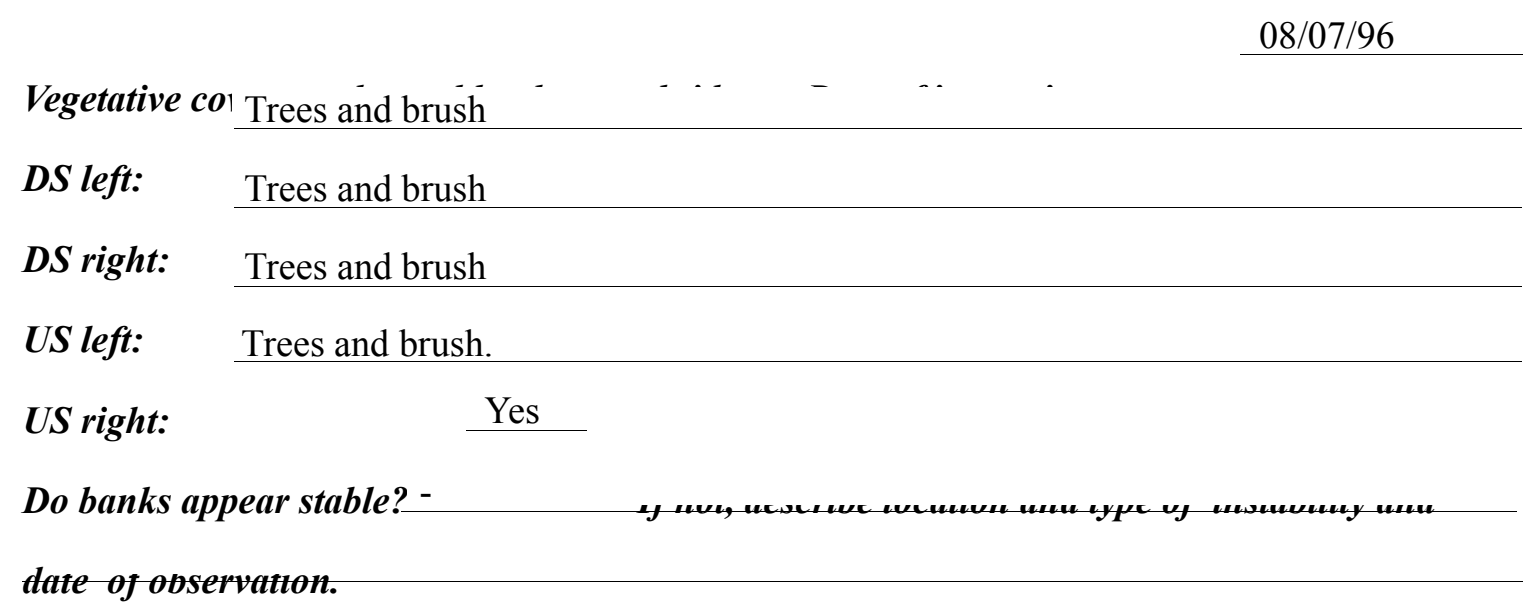

None 08/07/96.

Describe any obstructions in channel and date of observation. 


\title{
Hydrology
}

Drainage area $\stackrel{6.48}{\mathbf{m i}} \mathbf{i}^{2}$

Percentage of drainage area in physiographic provinces: (approximate)

Physiographic province/section

New England/Green Mountain
Percent of drainage area 100

\begin{abstract}
Is drainage area considered rural or urban?
Rural None.

urbanization:

Describe any significant
\end{abstract}

Is there a USGS gage on the stream of interest?
USGS gage description

No

USGS gage description

USGS gage number

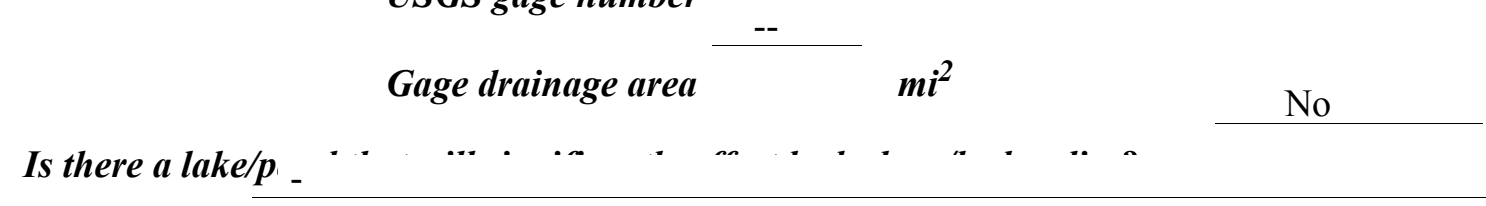

Is there a lake/p.

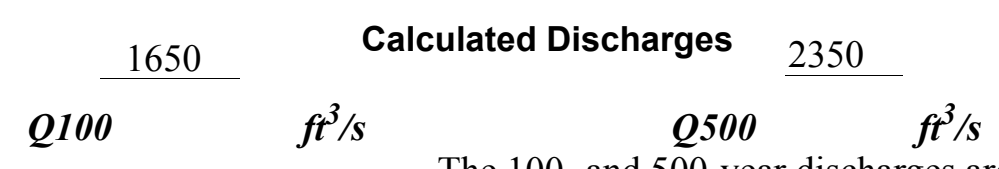

The 100- and 500-year discharges are based on

a drainage area relationship [(6.48/5.60)exp 0.67] with bridge number 4 in Winhall.

Bridge number 4 crosses Cook Brook upstream of this site and has flood frequency estimates available from the VTAOT database. The drainage area above bridge number 4 is 5.6 square miles. These values are within a range defined by several empirical flood frequency curves.(Benson, 1962; Johnson and Tasker, 1974; FHWA, 1983; Potter, 1957a\&b; Talbot, 1887) 


\section{Description of the Water-Surface Profile Model (WSPRO) Analysis}

Datum for WSPRO analysis (USGS survey, sea level, VTAOT plans)

USGS survey

Datum tie between USGS survey and VTAOT plans

None

Description of reference marks used to determine USGS datum. $\quad$ RM1 is at the

downstream shoreward corner of a chiseled square at the upstream end of the left abutment (elev. $499.43 \mathrm{ft}$, arbitrary survey datum). RM2 is a chiseled X on top of the downstream end of

the right abutment (elev. $499.79 \mathrm{ft}$, arbitrary survey datum).

\section{Cross-Sections Used in WSPRO Analysis}

\begin{tabular}{|c|c|c|c|}
\hline${ }^{1}$ Cross-section & $\begin{array}{c}\text { Section } \\
\text { Reference } \\
\text { Distance } \\
(\text { SRD) in feet }\end{array}$ & $\begin{array}{c}{ }^{2} \text { Cross-section } \\
\text { development }\end{array}$ & Comments \\
\hline EXITX & -23 & 1 & Exit section \\
\hline FULLV & 0 & 2 & $\begin{array}{l}\text { Downstream Full-valley } \\
\text { section (Templated from } \\
\text { EXITX) }\end{array}$ \\
\hline BRIDG & 0 & 1 & Bridge section \\
\hline RDWAY & 11 & 1 & Road Grade section \\
\hline APTEM & 36 & 1 & $\begin{array}{l}\text { Approach section as } \\
\text { surveyed (Used as a } \\
\text { template) }\end{array}$ \\
\hline APPRO & 42 & 2 & $\begin{array}{l}\text { Modelled Approach sec- } \\
\text { tion (Templated from } \\
\text { APTEM) }\end{array}$ \\
\hline
\end{tabular}

${ }^{1}$ For location of cross-sections see plan-view sketch included with Level I field form, Appendix E. For more detail on how cross-sections were developed see WSPRO input file. 


\section{Data and Assumptions Used in WSPRO Model}

Hydraulic analyses of the reach were done by use of the Federal Highway Administration's WSPRO step-backwater computer program (Shearman and others, 1986, and Shearman, 1990). The analyses reported herein reflect conditions existing at the site at the time of the study. Furthermore, in the development of the model it was necessary to assume no accumulation of debris or ice at the site. Results of the hydraulic model are presented in the Bridge Hydraulic Summary, Appendix B, and figure 7.

Channel roughness factors (Manning's “ $n$ ”) used in the hydraulic model were estimated using field inspections at each cross section following the general guidelines described by Arcement and Schneider (1989). Final adjustments to the values were made during the modelling of the reach. Channel " $\mathrm{n}$ " values for the reach ranged from 0.055 to 0.065 , and overbank " $n$ " values ranged from 0.060 to 0.080 .

Normal depth at the exit section (EXITX) was assumed as the starting water surface. This depth was computed by use of the slope-conveyance method outlined in the user's manual for WSPRO (Shearman, 1990). The slope used was $0.0164 \mathrm{ft} / \mathrm{ft}$ which was estimated from the topographic map (U.S. Geological Survey, 1986).

The surveyed approach section (APTEM) was moved along the approach channel slope $(0.0313 \mathrm{ft} / \mathrm{ft})$ to establish the modelled approach section (APPRO), one bridge length upstream of the upstream face as recommended by Shearman and others (1986). This location also provides a consistent method for determining scour variables. 


\section{Bridge Hydraulics Summary}

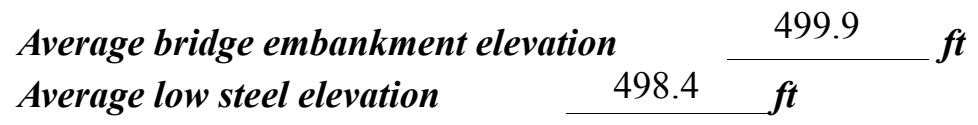

100-year discharge $\quad 1,650 \quad \mathrm{ft}^{3} / \mathrm{s}$

Water-surface elevation in bridge opening $\quad 498.5 \quad f t$

Road overtopping? ___ Y Discharge over road __ 83 $\mathrm{ft}^{3} / \mathrm{s}$

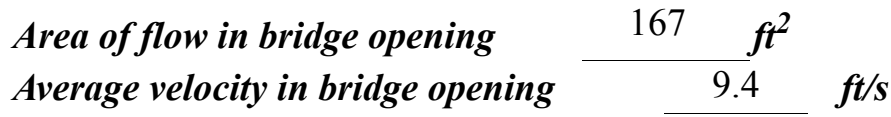

Maximum WSPRO tube velocity at bridge $11.5 \mathrm{ft} / \mathrm{s}$

Water-surface elevation at Approach section with bridge 500.6

Water-surface elevation at Approach section without bridge $\quad 497.7$

Amount of backwater caused by bridge

$2.9 \quad i$

500-year discharge $\quad 2,350 \quad \mathrm{ft}^{3} / \mathrm{s}$

Water-surface elevation in bridge opening $\quad 498.5 \mathrm{ft}$

Road overtopping? ___ Y Discharge over road _ $\quad 548 \quad \mathrm{ft}^{3} / \mathrm{s}$

Area of flow in bridge opening $\quad 167 \quad \mathrm{ft}^{2}$

Average velocity in bridge opening $10.8 \mathrm{ft} / \mathrm{s}$

Maximum WSPRO tube velocity at bridge 13.2 's

Water-surface elevation at Approach section with bridge 501.7

Water-surface elevation at Approach section without bridge $\quad 498.6$

Amount of backwater caused by bridge $\quad 3.1, t$

Incipient overtopping discharge $\quad 1,390 \mathrm{ft}^{3} / \mathrm{s}$

Water-surface elevation in bridge opening $498.5 \quad t$

Area of flow in bridge opening $\quad \begin{array}{lll}167 & \mathrm{ft}^{2}\end{array}$

Average velocity in bridge opening $\quad 8.3 \quad \mathrm{ft} / \mathrm{s}$

Maximum WSPRO tube velocity at bridge $\quad 10.2 \mathrm{ft} / \mathrm{s}$

Water-surface elevation at Approach section with bridge

499.9

Water-surface elevation at Approach section without bridge

497.3

Amount of backwater caused by bridge $\quad 2.6$.t 


\section{Scour Analysis Summary}

\section{Special Conditions or Assumptions Made in Scour Analysis}

Scour depths were computed using the general guidelines described in Hydraulic Engineering Circular 18 (Richardson and others, 1995). Scour depths were calculated assuming an infinite depth of erosive material and a homogeneous particle-size distribution. The results of the scour analysis are presented in tables 1 and 2 and a graph of the scour depths is presented in figure 8 .

Contraction scour was computed by use of the clear-water contraction scour equation (Richardson and others, 1995, p. 32, equation 20). At this site all discharges resulted in unsubmerged orifice flow. Contraction scour at bridges with orifice flow is best estimated by use of the Chang pressure-flow scour equation (oral communication, J. Sterling Jones, October 4, 1996). Thus, contraction scour was computed by use of the Chang equation (Richardson and others, 1995, p. 145-146). Results of this analysis are presented in figure 8 and tables 1 and 2 . The streambed armoring depths computed suggest that armoring will not limit the depth of contraction scour.

For all discharges resulting in orifice flow, estimates of contraction scour were also computed by use of the Laursen clear-water contraction scour equation and the Umbrell pressure-flow equation (Richardson and others, 1995, p. 144) and presented in Appendix F. Furthermore, for those discharges resulting in unsubmerged orifice flow, contraction scour was computed by substituting estimates for the depth of flow at the downstream bridge face in the contraction scour equations. Results with respect to these substitutions are provided in Appendix F.

Abutment scour was computed by use of the Froehlich equation (Richardson and others, 1995, p. 48, equation 28). Variables for the Froehlich equation include the Froude number of the flow approaching the embankments, the length of the embankment blocking flow, and the depth of flow approaching the embankment less any roadway overtopping. 


\section{Scour Results}

100-yr discharge 500-yr discharge

Contraction scour:

(Scour depths in feet)

Main channel

Live-bed scour

Clear-water scour

Depth to armoring

Left overbank

Right overbank

Local scour:

Abutment scour

14.1

15.1

13.3

Left abutment

Right abutment

Pier scour

Pier 1

Pier 2

0.51 .5
$5.3^{-}$

0.0

$6 . \overline{45.8}$

$--$

$--$

--

$8.68 .7^{-}$

$8.4^{-}$
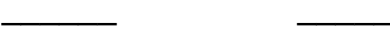

overtopping discharge

Pier 3

\section{Riprap Sizing}

\section{Abutments:}

\section{Left abutment}

\section{Right abutment}

Piers:

Pier 1

Pier 2

Incipient overtopping 100-yrdischarge 500-yrdischarge discharge

2.3

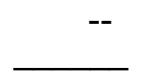

$-{ }^{-}$

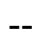

$$
\text { ( } D_{50} \text { in feet) }
$$

2.3

2.1

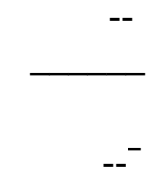

2.1 


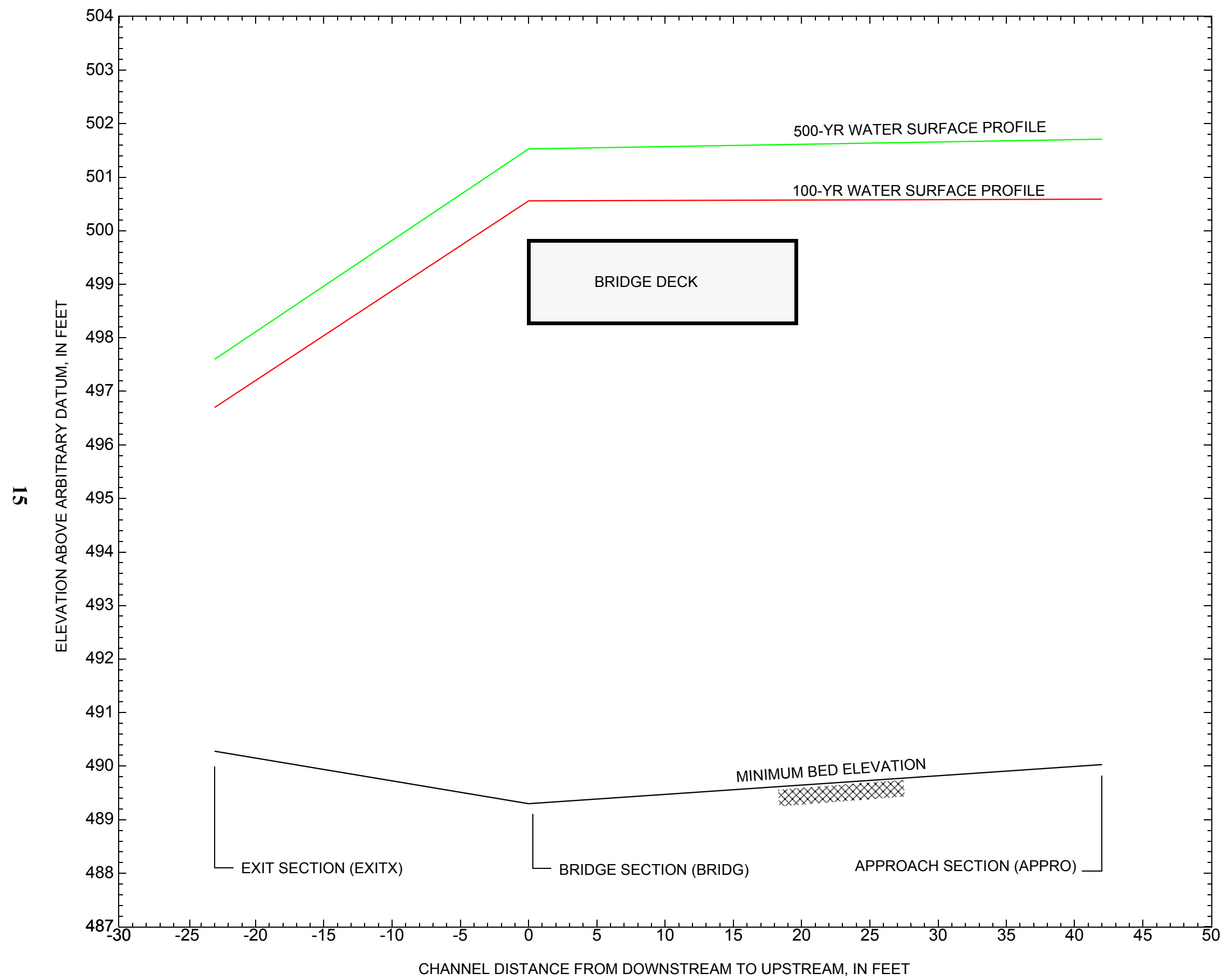

Figure 7. Water-surface profiles for the 100- and 500-yr discharges at structure LONDTH00410029 on Town Highway 41, crossing Cook Brook, Londonderry, Vermont. 


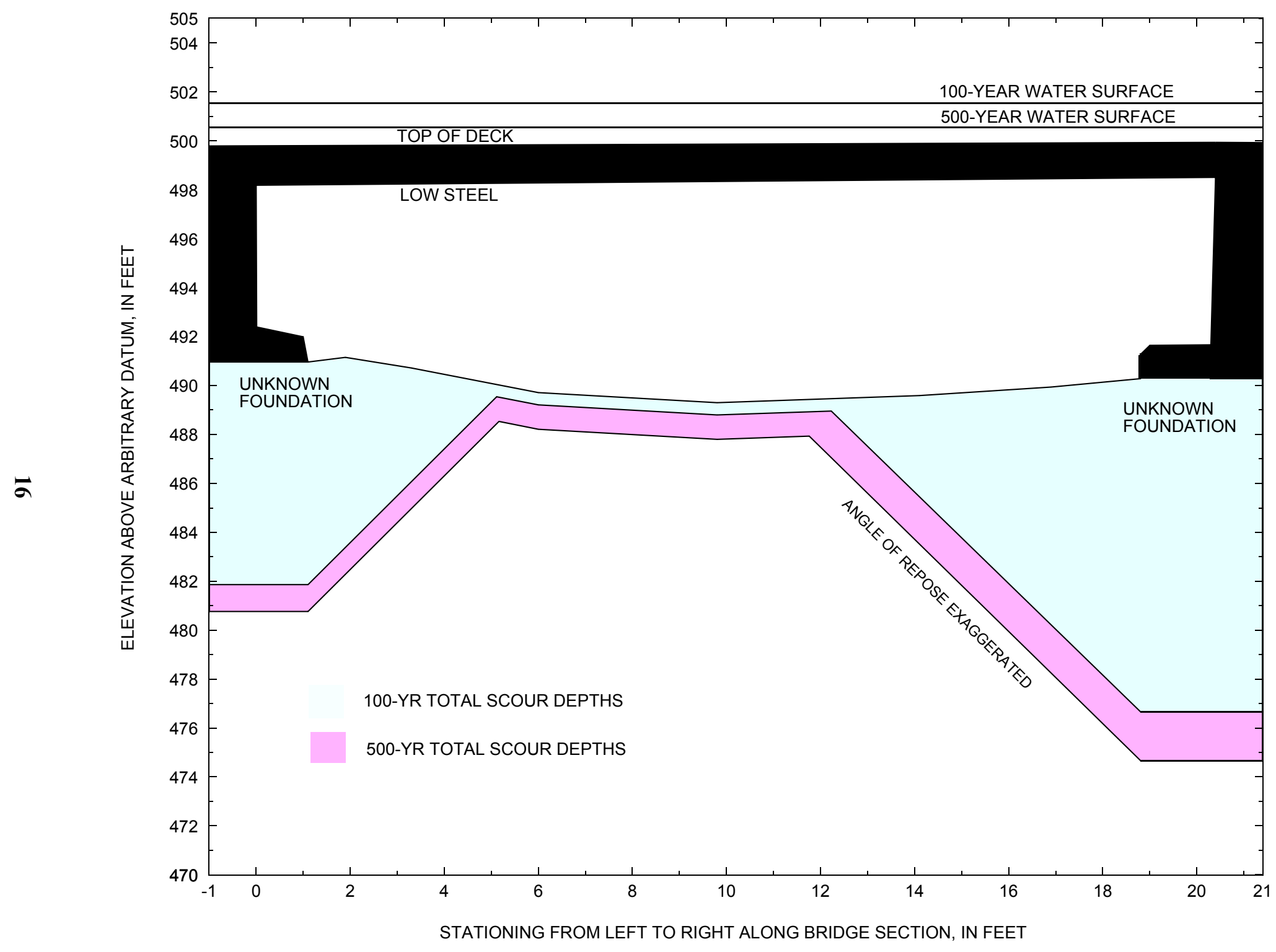

Figure 8. Scour elevations for the 100-yr and 500-yr discharges at structure LONDTH00410029 on Town Highway 41, crossing Cook Brook, Londonderry, Vermont. 
Table 1. Remaining footing/pile depth at abutments for the 100-year discharge at structure LONDTH00410029 on Town Highway 41, crossing Cook Brook, Londonderry, Vermont.

[VTAOT, Vermont Agency of Transportation; --,no data]

\begin{tabular}{|c|c|c|c|c|c|c|c|c|c|c|c|}
\hline Description & Station ${ }^{1}$ & $\begin{array}{l}\text { VTAOT } \\
\text { minimum } \\
\text { low-chord } \\
\text { elevation } \\
\text { (feet) }\end{array}$ & $\begin{array}{l}\text { Surveyed } \\
\text { minimum } \\
\text { low-chord } \\
\text { elevation }{ }^{2} \\
\text { (feet) }\end{array}$ & $\begin{array}{l}\text { Bottom of } \\
\text { footing } \\
\text { elevation }{ }^{2} \\
\text { (feet) }\end{array}$ & $\begin{array}{c}\text { Channel } \\
\text { elevation at } \\
\text { abutment/ } \\
\text { pier }^{2} \\
\text { (feet) }\end{array}$ & $\begin{array}{l}\text { Contraction } \\
\text { scour depth } \\
\text { (feet) }\end{array}$ & $\begin{array}{l}\text { Abutment } \\
\text { scour } \\
\text { depth } \\
\text { (feet) }\end{array}$ & $\begin{array}{l}\text { Pier } \\
\text { scour } \\
\text { depth } \\
\text { (feet) }\end{array}$ & $\begin{array}{l}\text { Depth of } \\
\text { total scour } \\
\text { (feet) }\end{array}$ & $\begin{array}{c}\text { Elevation of } \\
\text { scour }^{2} \\
\text { (feet) }\end{array}$ & $\begin{array}{c}\text { Remaining } \\
\text { footing/pile } \\
\text { depth } \\
\text { (feet) }\end{array}$ \\
\hline \multicolumn{12}{|c|}{100 -yr. discharge is 1650 cubic-feet per second } \\
\hline Left abutment & 0.0 & -- & 498.2 & -- & 491.0 & 0.5 & 8.6 & -- & 9.1 & 481.9 & -- \\
\hline Right abutment & 20.4 & -- & 498.5 & -- & 490.3 & 0.5 & 14.1 & -- & 14.6 & 475.7 & -- \\
\hline
\end{tabular}

1.Measured along the face of the most constricting side of the bridge.

2.Arbitrary datum for this study.

Table 2. Remaining footing/pile depth at abutments for the 500-year discharge at structure LONDTH00410029 on Town Highway 41, crossing Cook Brook, Londonderry, Vermont.

[VTAOT, Vermont Agency of Transportation; --, no data]

\begin{tabular}{|c|c|c|c|c|c|c|c|c|c|c|c|}
\hline Description & Station $^{1}$ & $\begin{array}{l}\text { VTAOT } \\
\text { minimum } \\
\text { low-chord } \\
\text { elevation } \\
\text { (feet) }\end{array}$ & $\begin{array}{c}\text { Surveyed } \\
\text { minimum } \\
\text { low-chord } \\
\text { elevation } \\
\text { (feet) }\end{array}$ & $\begin{array}{l}\text { Bottom of } \\
\text { footing } \\
\text { elevation } \\
\text { (feet) }\end{array}$ & $\begin{array}{c}\text { Channel } \\
\text { elevation at } \\
\text { abutment/ } \\
\text { pier }^{2} \\
\text { (feet) }\end{array}$ & $\begin{array}{l}\text { Contraction } \\
\text { scour depth } \\
\text { (feet) }\end{array}$ & $\begin{array}{c}\text { Abutment } \\
\text { scour } \\
\text { depth } \\
\text { (feet) }\end{array}$ & $\begin{array}{l}\text { Pier } \\
\text { scour } \\
\text { depth } \\
\text { (feet) }\end{array}$ & $\begin{array}{l}\text { Depth of } \\
\text { total scour } \\
\text { (feet) }\end{array}$ & $\begin{array}{c}\text { Elevation of } \\
\text { scour }^{2} \\
\text { (feet) }\end{array}$ & $\begin{array}{c}\text { Remaining } \\
\text { footing/pile } \\
\text { depth } \\
\text { (feet) }\end{array}$ \\
\hline \multicolumn{12}{|c|}{500 -yr. discharge is 2350 cubic-feet per second } \\
\hline Left abutment & 0.0 & -- & 498.2 & -- & 491.0 & 1.5 & 8.7 & -- & 10.2 & 480.8 & -- \\
\hline Right abutment & 20.4 & -- & 498.5 & -- & 490.3 & 1.5 & 15.1 & -- & 16.6 & 473.7 & -- \\
\hline
\end{tabular}

1.Measured along the face of the most constricting side of the bridge.

2.Arbitrary datum for this study. 


\section{SELECTED REFERENCES}

Arcement, G.J., Jr., and Schneider, V.R., 1989, Guide for selecting Manning's roughness coefficients for natural channels and flood plains: U.S. Geological Survey Water-Supply Paper 2339, 38 p.

Barnes, H.H., Jr., 1967, Roughness characteristics of natural channels: U.S. Geological Survey Water-Supply Paper 1849,213 p.

Benson, M. A., 1962, Factors Influencing the Occurrence of Floods in a Humid Region of Diverse Terrain: U.S. Geological Survey WaterSupply Paper 1580-B, 64 p.

Brown, S.A. and Clyde, E.S., 1989, Design of riprap revetment: Federal Highway Administration Hydraulic Engineering Circular No. 11, Publication FHWA-IP-89-016, 156 p.

Federal Highway Administration, 1983, Runoff estimates for small watersheds and development of sound design: Federal Highway Administration Report FHWA-RD-77-158.

Federal Highway Administration, 1993, Stream Stability and Scour at Highway Bridges: Participant Workbook: Federal Highway Administration Report FHWA-HI-91-011.

Federal Emergency Management Agency, 1986, Flood Insurance Study, Town of Lincoln, Addision County, Vermont: Washington, D.C., August 1986.

Froehlich, D.C., 1989, Local scour at bridge abutments in Ports, M.A., ed., Hydraulic Engineering--Proceedings of the 1989 National Conference on Hydraulic Engineering: New York, American Society of Civil Engineers, p. 13-18.

Hayes, D.C.,1993, Site selection and collection of bridge-scour data in Delaware, Maryland, and Virginia: U.S. Geological Survey WaterResources Investigation Report 93-4017, 23 p.

Interagency Advisory Committee on Water Data, 1982, Guidelines for determining flood flow frequency: U.S. Geological Survey, Bulletin 17B of the Hydrology Subcommittee, 190 p.

Johnson, C.G. and Tasker, G.D.,1974, Progress report on flood magnitude and frequency of Vermont streams: U.S. Geological Survey OpenFile Report 74-130, 37 p.

Lagasse, P.F., Schall, J.D., Johnson, F., Richardson, E.V., Chang, F., 1995, Stream Stability at Highway Structures: Federal Highway Administration Hydraulic Engineering Circular No. 20, Publication FHWA-IP-90-014, 144 p.

Laursen, E.M., 1960, Scour at bridge crossings: Journal of the Hydraulics Division, American Society of Civil Engineers, v. 86, no. HY2, p. 39-53.

Potter, W. D., 1957a, Peak rates of runoff in the Adirondack, White Mountains, and Maine woods area, Bureau of Public Roads

Potter, W. D., 1957b, Peak rates of runoff in the New England Hill and Lowland area, Bureau of Public Roads

Richardson, E.V. and Davis, S.R., 1995, Evaluating scour at bridges: Federal Highway Administration Hydraulic Engineering Circular No. 18, Publication FHWA-IP-90-017, 204 p.

Richardson, E.V., Simons, D.B., and Julien, P.Y., 1990, Highways in the river environment: Federal Highway Administration Publication FHWA-HI-90-016.

Ritter, D.F., 1984, Process Geomorphology: W.C. Brown Co., Debuque, Iowa, 603 p.

Shearman, J.O., 1990, User's manual for WSPRO--a computer model for water surface profile computations: Federal Highway Administration Publication FHWA-IP-89-027, 187 p.

Shearman, J.O., Kirby, W.H., Schneider, V.R., and Flippo, H.N., 1986, Bridge waterways analysis model; research report: Federal Highway Administration Publication FHWA-RD-86-108, 112 p.

Talbot, A.N., 1887, The determination of water-way for bridges and culverts.

U.S. Department of Transportation, 1993, Stream stability and scour at highway bridges, Participant Workbook: Federal Highway Administration Publication FHWA HI-91-011.

U.S. Geological Survey, 1986, Londonderry, Vermont 7.5 Minute Series quadrangle map: U.S. Geological Survey Topographic Maps, Scale $1: 24,000$. 


\section{APPENDIX A: \\ WSPRO INPUT FILE}




\section{WSPRO INPUT FILE}

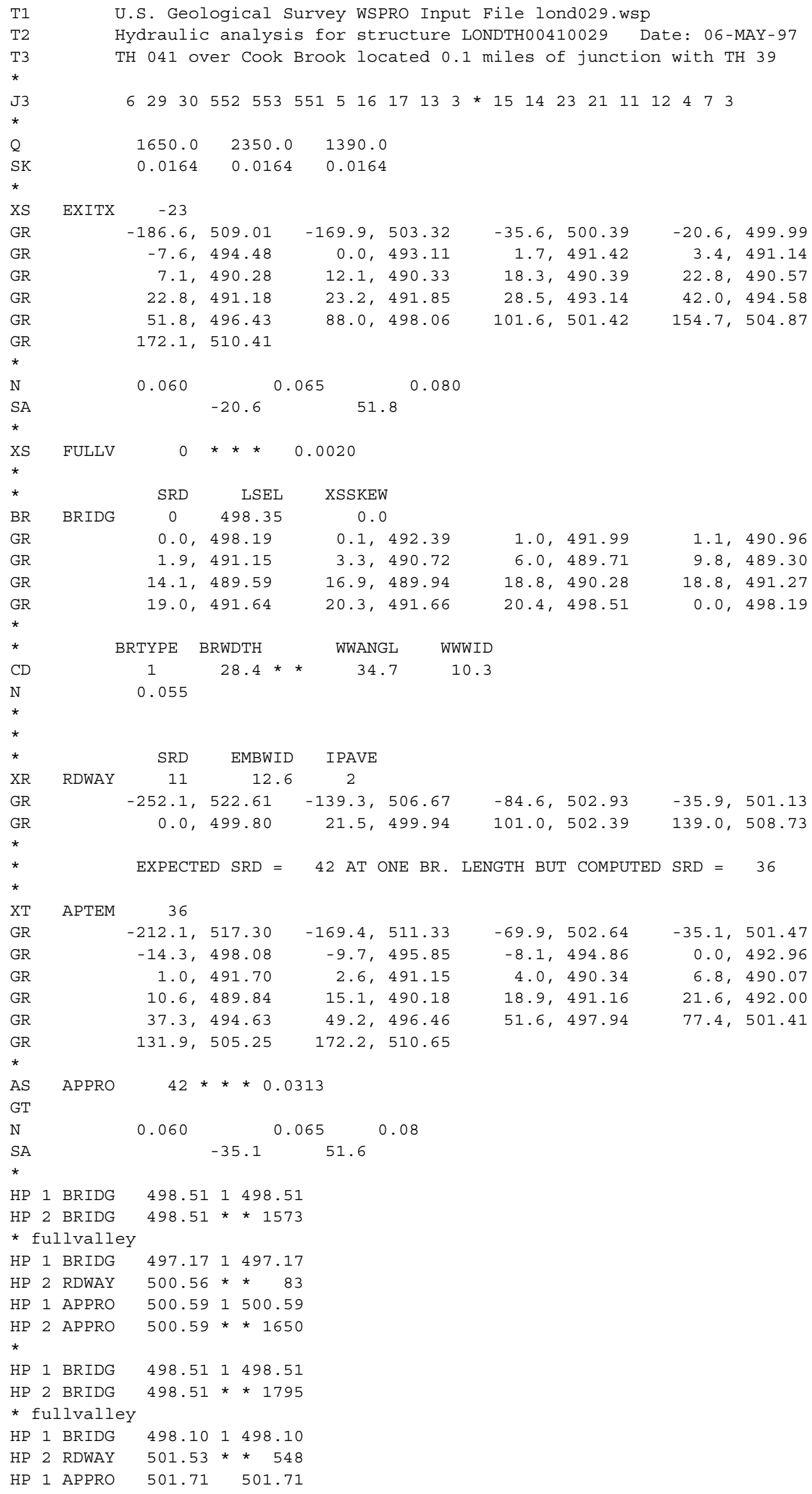




\section{APPENDIX B: \\ WSPRO OUTPUT FILE}


U.S. Geological Survey WSPRO Input File lond029.wsp

Hydraulic analysis for structure LONDTH00410029 Date: 06-MAY-97 TH 041 over Cook Brook located 0.1 miles of junction with TH 39

*** RUN DATE \& TIME: 06-02-97 13:32

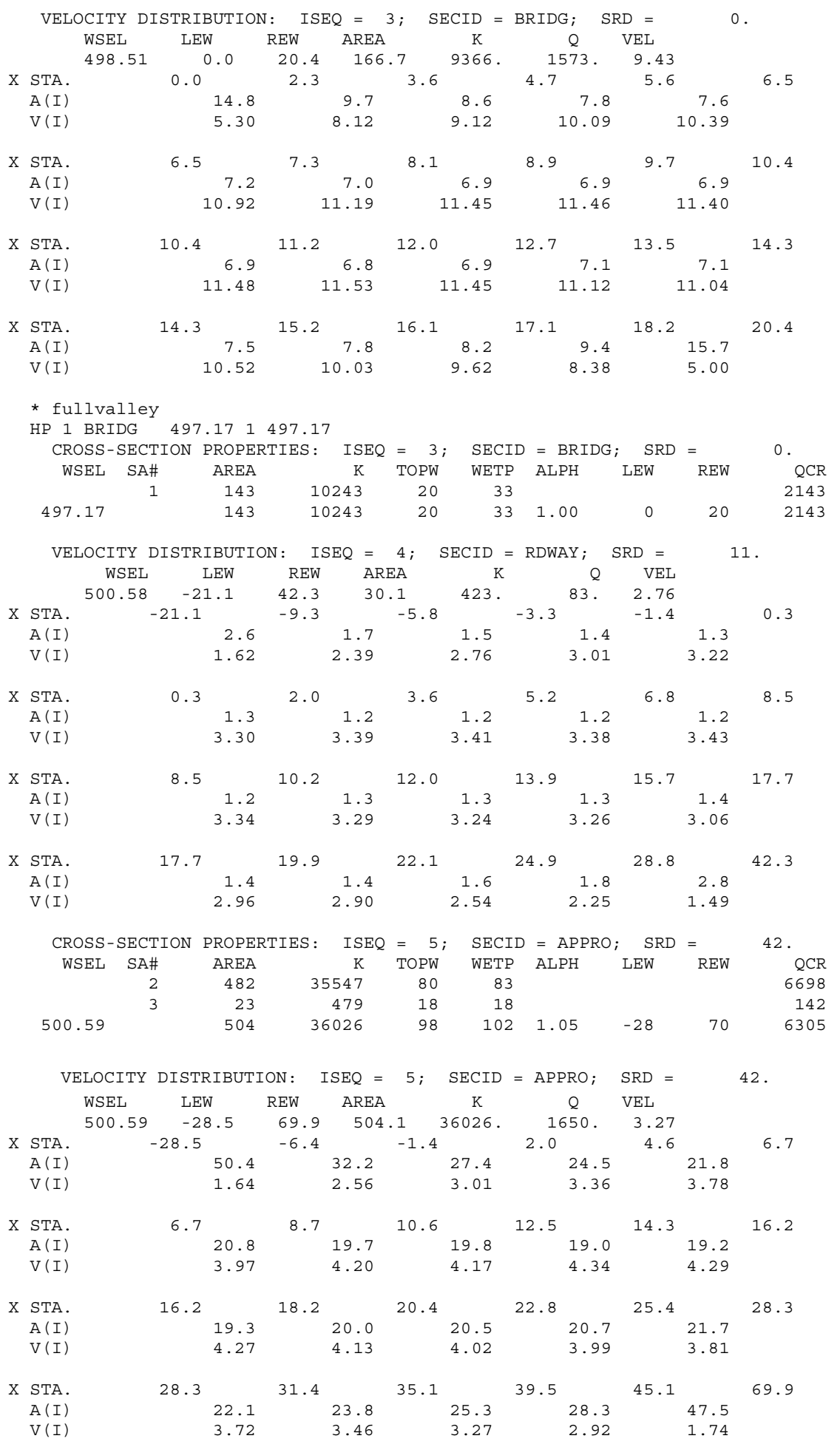


WSPRO OUTPUT FILE (continued)

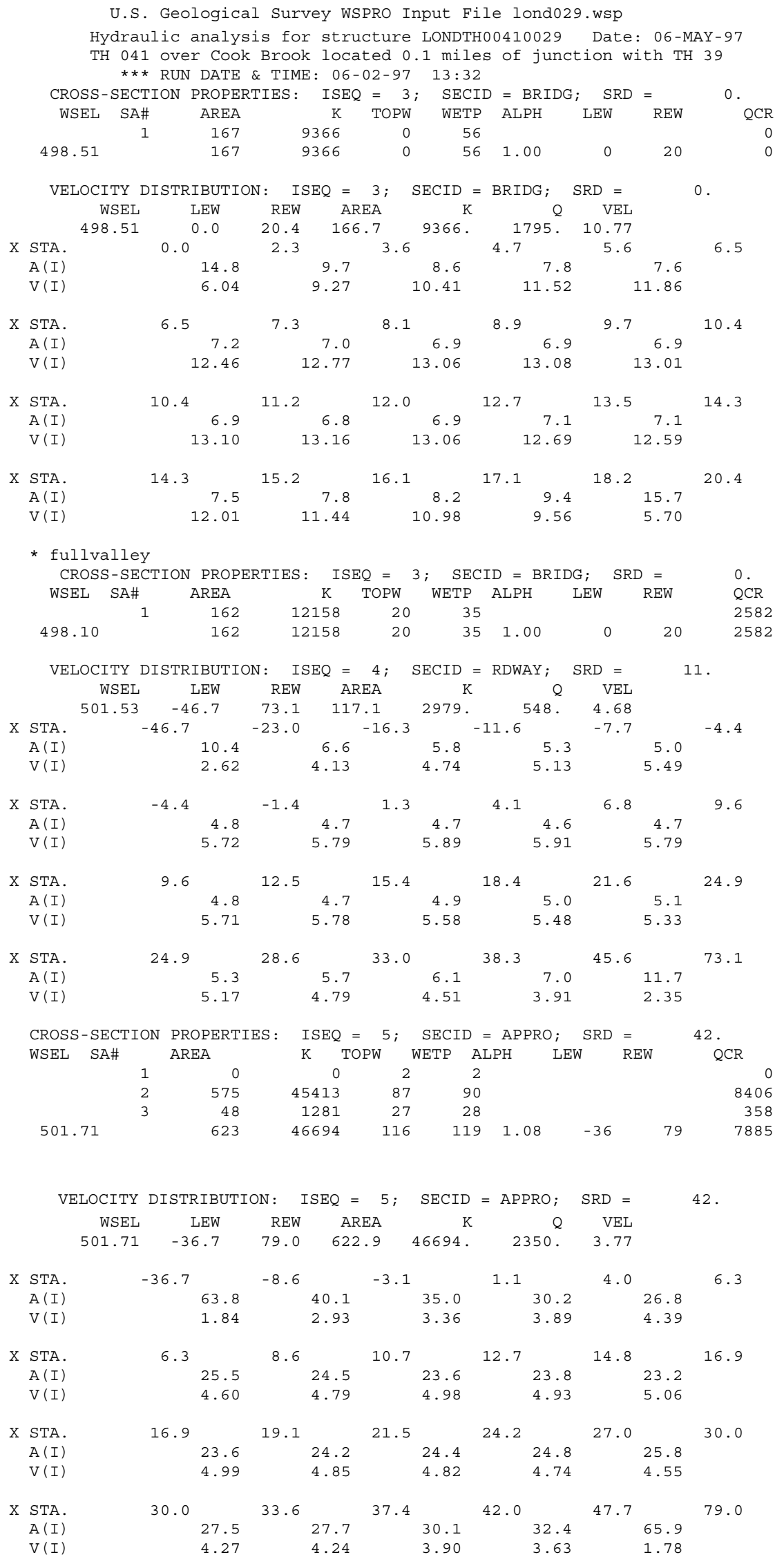


WSPRO OUTPUT FILE (continued)

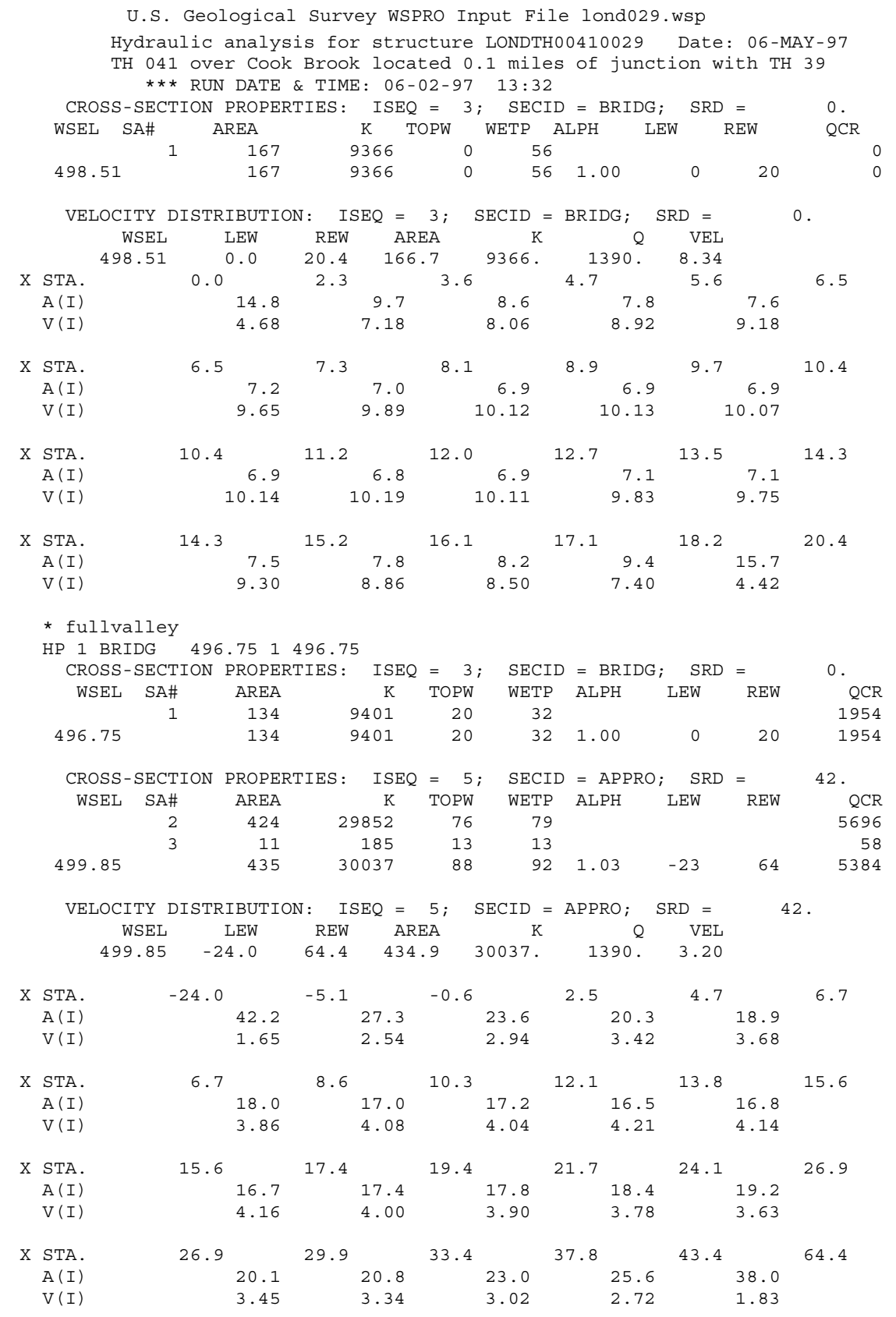




\section{WSPRO OUTPUT FILE (continued)}

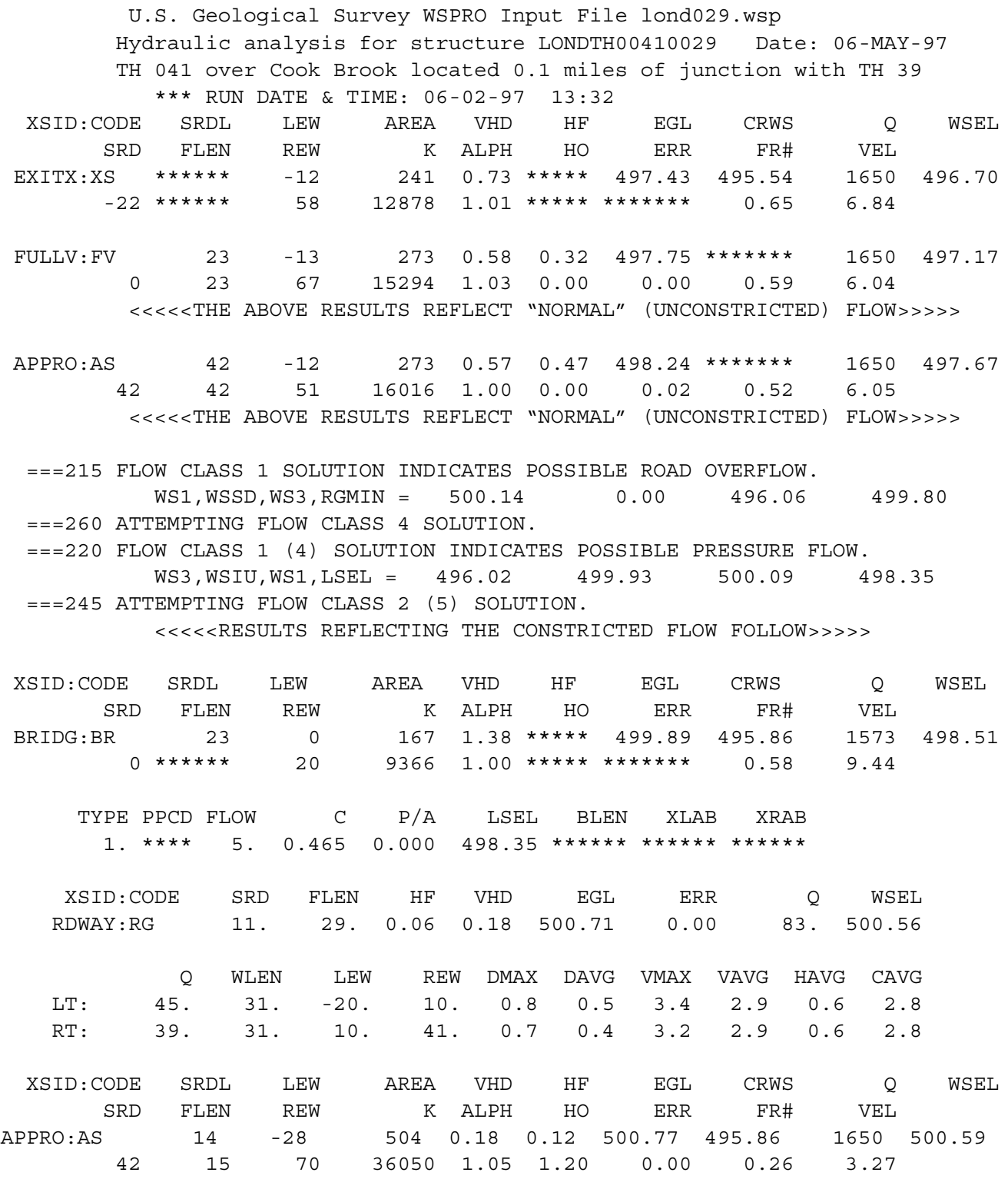

FIRST USER DEFINED TABLE.

$\begin{array}{lrrrrrrrr}\text { XSID : CODE } & \text { SRD } & \text { LEW } & \text { REW } & Q & \text { K } & \text { AREA } & \text { VEL } & \text { WSEL } \\ \text { EXITX : XS } & -23 . & -13 . & 58 . & 1650 . & 12878 . & 241 . & 6.84 & 496.70 \\ \text { FULLV : FV } & 0 . & -14 . & 67 . & 1650 . & 15294 . & 273 . & 6.04 & 497.17 \\ \text { BRIDG : BR } & 0 . & 0 . & 20 . & 1573 . & 9366 . & 167 . & 9.44 & 498.51 \\ \text { RDWAY : RG } & 11 . * * * * * * & 45 . & 83 . * * * * * * * * * * * * * * * & 2.00 & 500.56 \\ \text { APPRO : AS } & 42 . & -29 . & 70 . & 1650 . & 36050 . & 504 . & 3.27 & 500.59\end{array}$

SECOND USER DEFINED TABLE.

$\begin{array}{lccccccccc}\text { XSID : CODE } & \text { CRWS } & \text { FR\# } & \text { YMIN } & \text { YMAX } & \text { HF } & \text { HO } & \text { VHD } & \text { EGL } & \text { WSEL } \\ \text { EXITX:XS } & 495.54 & 0.65 & 490.28 & 510.41 * * * * * * * * * * & 0.73 & 497.43 & 496.70 \\ \text { FULLV: }: \text { V } & * * * * * * * & 0.59 & 490.33 & 510.46 & 0.32 & 0.00 & 0.58 & 497.75 & 497.17 \\ \text { BRIDG : BR } & 495.86 & 0.58 & 489.30 & 498.51 * * * * * * * * * * & 1.38 & 499.89 & 498.51 \\ \text { RDWAY: RG } & * * * * * * * * * * * * * * * & 499.80 & 522.61 & 0.06 * * * * * * & 0.18 & 500.71 & 500.56 \\ \text { APPRO:AS } & 495.86 & 0.26 & 490.03 & 517.49 & 0.12 & 1.20 & 0.18 & 500.77 & 500.59\end{array}$




\section{WSPRO OUTPUT FILE (continued)}

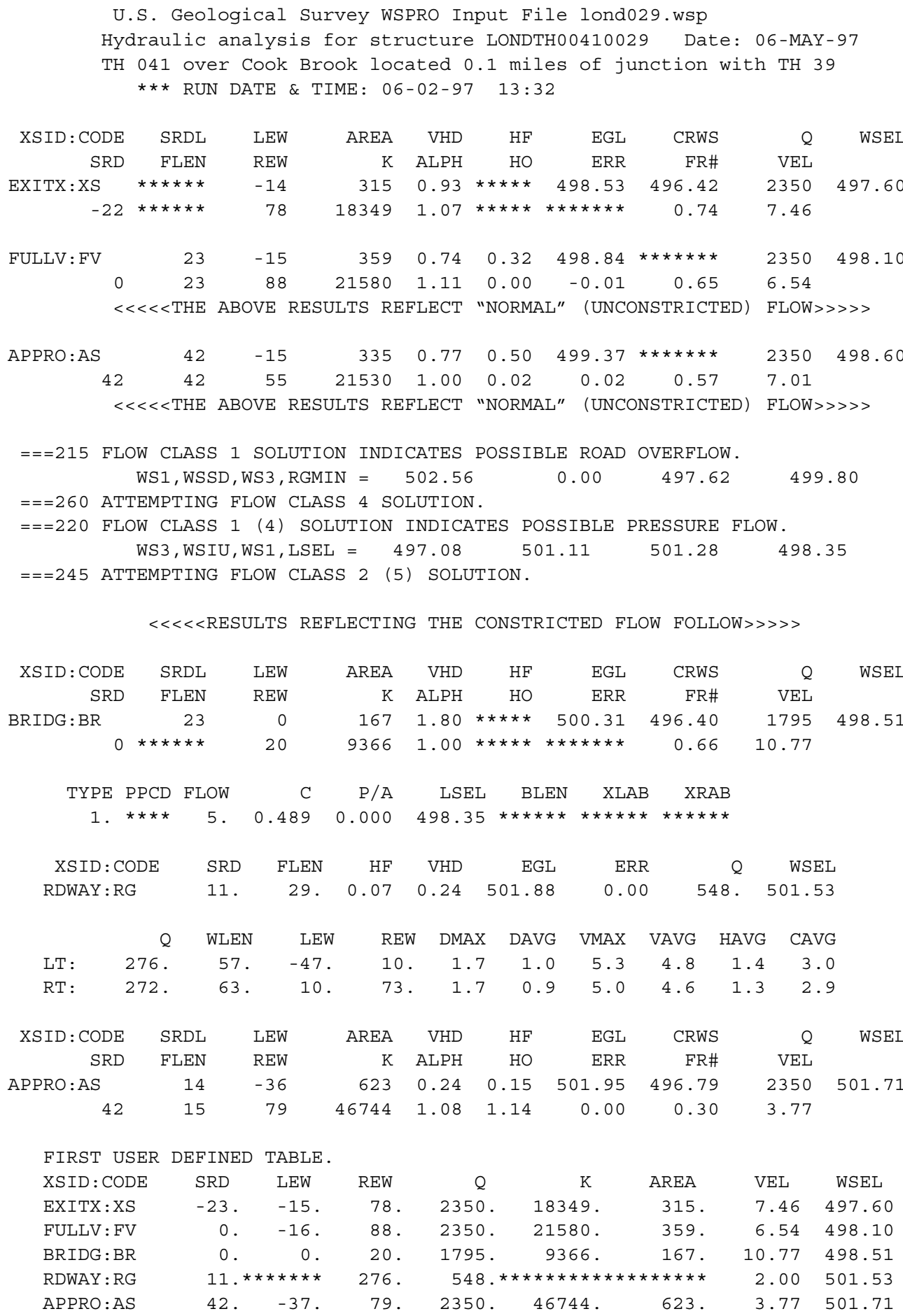

SECOND USER DEFINED TABLE.

$\begin{array}{lccccccccc}\text { XSID : CODE } & \text { CRWS } & \text { FR\# } & \text { YMIN } & \text { YMAX } & \text { HF } & \text { HO } & \text { VHD } & \text { EGL } & \text { WSEL } \\ \text { EXITX: }: \text { S } & 496.42 & 0.74 & 490.28 & 510.41 * * * * * * * * * * & 0.93 & 498.53 & 497.60 \\ \text { FULLV: }: F V & * * * * * * * & 0.65 & 490.33 & 510.46 & 0.32 & 0.00 & 0.74 & 498.84 & 498.10 \\ \text { BRIDG: BR } & 496.40 & 0.66 & 489.30 & 498.51 * * * * * * * * * * & 1.80 & 500.31 & 498.51 \\ \text { RDWAY: RG } & * * * * * * * * * * * * * * * & 499.80 & 522.61 & 0.07 * * * * * * & 0.24 & 501.88 & 501.53 \\ \text { APPRO:AS } & 496.79 & 0.30 & 490.03 & 517.49 & 0.15 & 1.14 & 0.24 & 501.95 & 501.71\end{array}$




\section{WSPRO OUTPUT FILE (continued)}

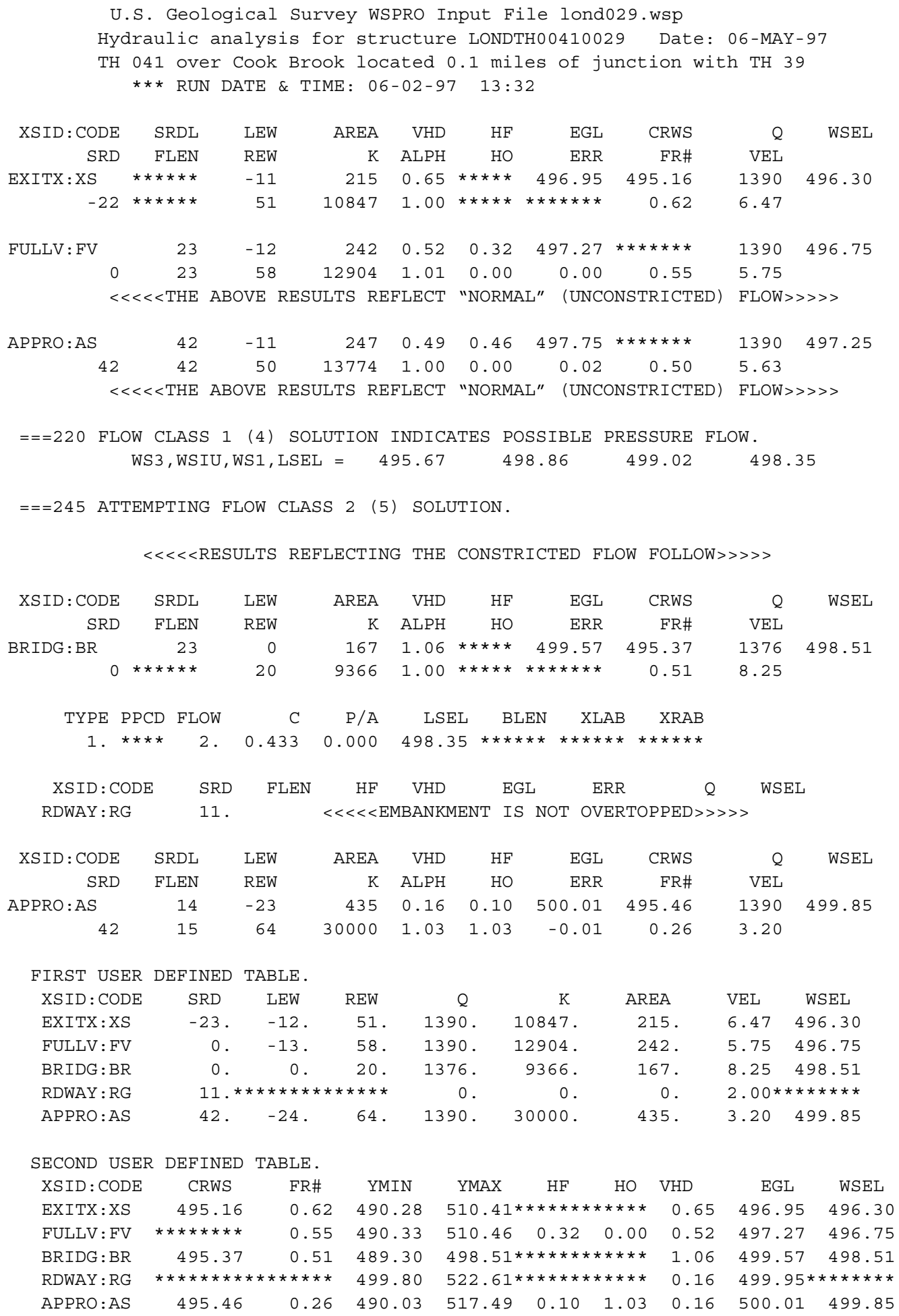




\section{APPENDIX C:}

\section{BED-MATERIAL PARTICLE-SIZE DISTRIBUTION}




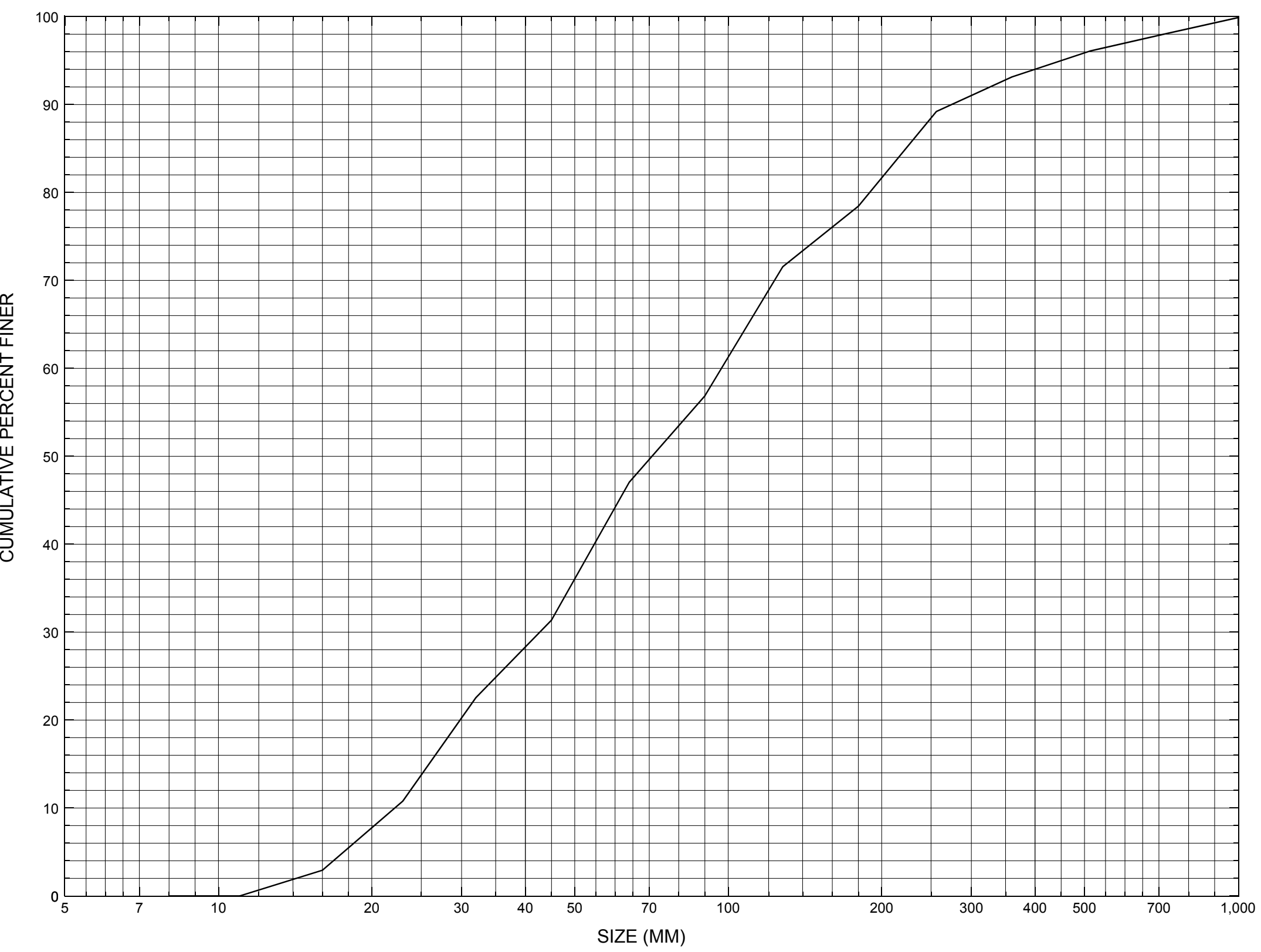

Appendix C. Bed material particle-size distribution for a pebble count in the channel approach of structure LONDTH00410029, in Londonderry, Vermont. 


\section{APPENDIX D: \\ HISTORICAL DATA FORM}




\section{Structure Number LONDTH00410029}

\section{General Location Descriptive}

Data collected by (First Initial, Full last name) $\underline{\text { M. IVANOFF }}$

Date $(M M / D D / Y Y) \_\mathbf{0 4} / \underline{06} / \underline{95}$

Highway District Number (I - 2; nn) $\mathbf{0 2}$

Town (FIPS place code; I - 4; nnnnn) $\mathbf{4 0 2 2 5}$

Waterway (I - 6) COOK BROOK

Route Number $\underline{\text { TH041 }}$

Topographic Map Londonderry

Latitude (I - 16; nnnn.n) $\mathbf{4 3 1 1 3}$
County (FIPS county code; I - 3; nnn)

Mile marker (I - 11; nnn.nnn) $\mathbf{0 0 0 0 0 0}$

Road Name (I - 7): -

Vicinity (l - 9) 0.1 MI JCT TH 41 \& TH 39

Hydrologic Unit Code: $\mathbf{0 1 0 8 0 1 0 7}$

Longitude (i - 17; nnnnn.n) $\mathbf{7 2 5 1 3}$

\section{Select Federal Inventory Codes}

FHWA Structure Number (I - 8) 10131000291310

Maintenance responsibility $(I-21 ; n n) \quad \mathbf{0 3}$

Year built (I - 27; YYYY) 1950

Average daily traffic, ADT (I - 29; nnnnnn) 000030

Year of ADT (I - 30; YY) $\mathbf{9 1}$

Opening skew to Roadway $(I-34 ; n n) \quad \mathbf{0 0}$

Operational status $(I-41 ; X) \quad \mathbf{P}$

Structure type (I- 43; nnn) $\mathbf{3 0 2}$

Approach span structure type $(I-44 ; n n n) \quad \mathbf{0 0 0}$

Number of spans (I - 45; nnn) $\mathbf{0 0 1}$

Number of approach spans (I - 46; nnnn) $\mathbf{0 0 0 0}$

Comments:

The structural inspection report of $09 / 15 / 93$ indicates the structure is a steel beam type bridge with a timber deck. Both concrete abutment walls have only a couple of hairline cracks and stains reported. The report also states that the footings are exposed. The streambed along the right abutment is roughly 12 inches below the top of footing. At the left abutment the bed is 2 feet below the top of the footing, and there is some very shallow undermining beneath the footing. In a few locations, the range pole can be shoved up to 3 feet behind the front face of the footing. There are some random boulders in view beneath the footing. Overall, the abutment appears stable. The streambed consists of stone and gravel, with some silt deposits. 


\section{Bridge Hydrologic Data}

Is there hydrologic data available? $\underline{\mathbf{N}}$ if No, type ctrl-n $h \quad$ VTAOT Drainage area $\left(m i^{2}\right)$ : -

Terrain character:

Stream character \& type: -

Streambed material:

Discharge Data (cfs):

$$
\begin{aligned}
& Q_{2.33}- \\
& Q_{50}-
\end{aligned}
$$

Record flood date $(M M / D D / Y Y)$ :

Estimated Discharge (cfs): Ice conditions (Heavy, Moderate, Light) : -

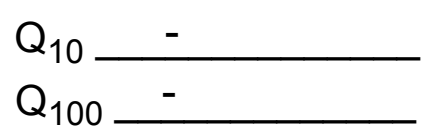

$$
\begin{aligned}
& Q_{25}- \\
& Q_{500}-
\end{aligned}
$$

Water surface elevation $(f t):-$

The stage increases to maximum highwater elevation (Rapidly, Not rapidly):

The stream response is (Flashy, Not flashy):

Describe any significant site conditions upstream or downstream that may influence the stream's stage: -

Watershed storage area (in percent): _ _ \%

The watershed storage area is: - (1-mainly at the headwaters; 2- uniformly distributed; 3-immediatly upstream oi the site)

Water Surface Elevation Estimates for Existing Structure:

\begin{tabular}{|l|l|l|l|l|l|}
\hline Peak discharge frequency & $Q_{2.33}$ & $Q_{10}$ & $Q_{25}$ & $Q_{50}$ & $Q_{100}$ \\
Water surface elevation (ft)) & - & - & - & - & - \\
Velocity (ft/sec) & - & - & - & - & - \\
\hline
\end{tabular}

Long term stream bed changes: -

Is the roadway overtopped below the $\mathrm{Q}_{100}$ ? (Yes, No, Unknown): $\mathbf{U}$ Frequency: Relief Elevation (ft): Discharge over roadway at $Q_{100}\left(f^{3} / \mathrm{sec}\right)$ :

Are there other structures nearby? (Yes, No, Unknown): $\underline{\mathbf{U}}$ Upstream distance (miles): Town: If No or Unknown, type ctrl-n os Highway No. : Structure No. : Year Built:

Clear span (ft): Clear Height $(f t)$ : Full Waterway $\left(f^{2}\right)$ : 
Downstream distance (miles): Town: Year Built:

Highway No. : Structure No. : Structure Type:

Clear span (ft): Clear Height $(f t)$ : Full Waterway $\left(f^{2}\right)$ : -

Comments:

\section{USGS Watershed Data}

Watershed Hydrographic Data

Drainage area (DA) 6.48

Watershed storage (ST) $\mathrm{mi}^{2}$ Lake/pond/swamp area 0.02 $\mathrm{mi}^{2}$

Bridge site elevation 1043 $\mathrm{ft}$ $\%$

Main channel length 5.63 $\mathrm{mi}$

$10 \%$ channel length elevation 1260 $\mathrm{ft} \quad 85 \%$ channel length elevation $\mathrm{ft}$

Main channel slope $(S)$
(S) 205.29 $\mathrm{ft} / \mathrm{mi}$

Watershed Precipitation Data

Average site precipitation in

Average headwater precipitation in

Maximum 2yr-24hr precipitation event $(124,2)$ in

Average seasonal snowfall (Sn) $\mathrm{ft}$ 


\section{Bridge Plan Data}

Are plans available? $\mathbf{N} \quad$ If no, type ctrl-n pl Date issued for construction (MM / YYYY):

Project Number

Minimum channel bed elevation:

Low superstructure elevation: USLAB DSLAB USRAB DSRAB Benchmark location description:

There is no benchmark information available.

Reference Point (MSL, Arbitrary, Other): Datum (NAD27, NAD83, Other):

Foundation Type: 4

If 1: Footing Thickness

If 2: Pile Type: (1-Wood; 2-S

(1-

(1-Spreadfooting; 2-Pile; 3- Gravity; 4-Unknown)

Footing bottom elevation:

If 3 : Footing bottom elevation:
Is boring information available?

Foundation Material Type: 3

Briefly describe material at foundation bottom elevation or around piles:

There is no foundation material information available.

Comments:

There are no bridge plans available. 


\section{Cross-sectional Data}

Is cross-sectional data available? If no, type ctrl-n xs

Source (FEMA, VTAOT, Other)? $\mathbf{N}$

Comments:

There is no cross-section information available.

\begin{tabular}{|l|l|l|l|l|l|l|l|l|l|l|l|}
\hline Station & - & - & - & - & - & - & - & - & - & - & - \\
\hline Feature & - & - & - & - & - & - & - & - & - & - & - \\
\hline $\begin{array}{l}\text { Low cord } \\
\text { elevation }\end{array}$ & - & - & - & - & - & - & - & - & - & - & - \\
\hline $\begin{array}{l}\text { Bed } \\
\text { elevation }\end{array}$ & - & - & - & - & - & - & - & - & - & - & - \\
\hline $\begin{array}{l}\text { Low cord to } \\
\text { bed length }\end{array}$ & - & - & - & - & - & - & - & - & - & - & - \\
\hline Station & - & - & - & - & - & - & - & - & - & - & - \\
\hline Feature & - & - & - & - & - & - & - & - & - & - & - \\
\hline $\begin{array}{l}\text { Low cord } \\
\text { elevation }\end{array}$ & - & - & - & - & - & - & - & - & - & - & - \\
\hline $\begin{array}{l}\text { Bed } \\
\text { elevation }\end{array}$ & - & - & - & - & - & - & - & - & - & - & - \\
\hline $\begin{array}{l}\text { Low cord to } \\
\text { bed length }\end{array}$ & - & - & - & - & - & - & - & - & - & - & - \\
\hline
\end{tabular}

Source (FEMA, VTAOT, Other)?

Comments: There is no cross-section information available.

\begin{tabular}{|l|l|l|l|l|l|l|l|l|l|l|l|}
\hline Station & - & - & - & - & - & - & - & - & - & - & - \\
\hline Feature & - & - & - & - & - & - & - & - & - & - & - \\
\hline $\begin{array}{l}\text { Low cord } \\
\text { elevation }\end{array}$ & - & - & - & - & - & - & - & - & - & - & - \\
\hline $\begin{array}{l}\text { Bed } \\
\text { elevation }\end{array}$ & - & - & - & - & - & - & - & - & - & - & - \\
\hline $\begin{array}{l}\text { Low cord to } \\
\text { bed length }\end{array}$ & - & - & - & - & - & - & - & - & - & - & - \\
\hline Station & - & - & - & - & - & - & - & - & - & - & - \\
\hline Feature & - & - & - & - & - & - & - & - & - & - & - \\
\hline $\begin{array}{l}\text { Low cord } \\
\text { elevation }\end{array}$ & - & - & - & - & - & - & - & - & - & - & - \\
\hline $\begin{array}{l}\text { Bed } \\
\text { elevation }\end{array}$ & - & - & - & - & - & - & - & - & - & - & - \\
\hline $\begin{array}{l}\text { Low cord to } \\
\text { bed length }\end{array}$ & - & - & - & - & - & - & - & - & - & - & - \\
\hline
\end{tabular}




\section{APPENDIX E: \\ LEVEL I DATA FORM}


U. S. Geological Survey

Bridge Field Data Collection and Processing Form

Qa/Qc Check by: $\underline{\mathbf{R B}}$ Date: $\underline{1 / 23 / 97}$

\section{Structure Number}

LONDTH00410029

Computerized by: $\underline{\mathbf{R B}}$ Date: $1 / 23 / 97$

Reviewd by: LKS Date: $\underline{06 / 02 / 97}$

\section{A. General Location Descriptive}

1. Data collected by (First Initial, Full last name) E. WILD

2. Highway District Number $\mathbf{0 2}$

County WINDHAM (025)

Mile marker 0000

Waterway (I - 6) COOK BROOK

Route Number TH041

Town LONDONDERRY (40225)

Road Name SPRING HILL ROAD

Hydrologic Unit Code: $\mathbf{0 1 0 8 0 1 0 7}$

3. Descriptive comments:

The bridge is located 0.1 miles from the junction of TH41 and TH39, Livermore Rd.

\section{B. Bridge Deck Observations}
4. Surface cover... LBUS 5
RBUS 6
LBDS 5
RBDS 6
Overall 5

(2b us, ds,lb,rb: 1- Urban; 2- Suburban; 3- Row crops; 4- Pasture; 5- Shrub- and brushland; 6- Forest; 7- Wetland)
5. Ambient water surface... US 1
UB 1
DS 1
(1- pool; 2- riffle)

6. Bridge structure type 1 (1- single span; 2- multiple span; 3- single arch; 4- multiple arch; 5- cylindrical culvert; 6- box culvert; or 7- other)
7. Bridge length $\underline{\mathbf{2 5}}$
(feet)
Span length $\mathbf{2 2}$
(feet)
Bridge width 12.6 (feet)

\section{Road approach to bridge:}
8. LB 2
RB 2
( 0 even, 1- lower, 2- higher)
9. LB_2
RB $\underline{2}$
(1-Paved, 2- Not paved)

10. Embankment slope (run / rise in feet / foot)

US left

US right

\begin{tabular}{|c|c|c|c|}
\hline \multicolumn{2}{|c|}{ Protection } & \multirow{2}{*}{ 13.Erosion } & 14.Severity \\
\hline 11.Type & 12.Cond. & $\underline{\mathbf{2}}$ & $\mathbf{1}$ \\
\hline $\mathbf{0}$ & - & $\mathbf{2}$ & $\mathbf{1}$ \\
\hline $\mathbf{0}$ & - & $\underline{\mathbf{2}}$ & $\mathbf{1}$ \\
\hline $\mathbf{0}$ & - & $\underline{\mathbf{2}}$ & $\mathbf{1}$ \\
\hline $\mathbf{0}$ & - & $\underline{\mathbf{2}}$ & $\underline{\mathbf{1}}$ \\
\hline
\end{tabular}

Bank protection types: 0- none; 1- < 12 inches,

2- $<36$ inches; $3-<48$ inches;

4- < 60 inches; 5- wall / artificial levee

Bank protection conditions: 1- good; 2- slumped;

3- eroded; 4- failed

Erosion: 0 - none; 1- channel erosion; 2 -

road wash; 3- both; 4- other

Erosion Severity: 0 - none; 1- slight; 2- moderate; 3- severe

\section{Channel approach to bridge (BF):}

15. Angle of approach: 0

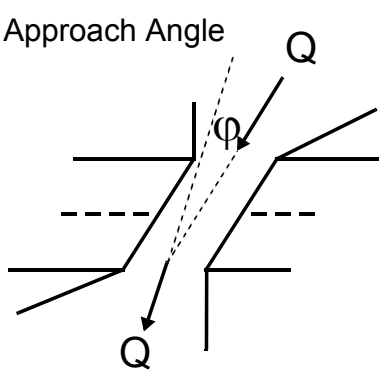

17. Channel impact zone 1:

Where? $(L B, R B)$

Range? feet -

Channel impact zone 2:

Where? $(L B, R B)$

Range? - $\quad$ feet -

(US, UB, DS) to feet Impact Severity: 0- none to very slight; 1- Slight; 2- Moderate; 3- Severe

16. Bridge skew: $\mathbf{5}$ Bridge Skew Angle

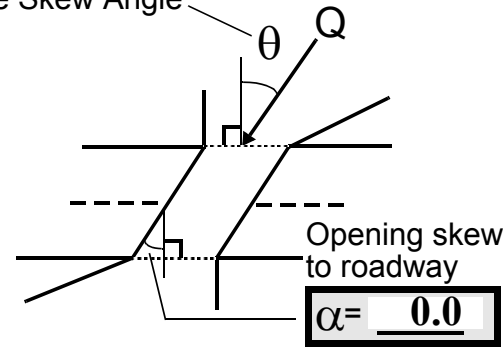

Exist? $\mathbf{N}(Y$ or $N)$

Severity

(US, UB, DS) to - $\quad$ feet -

Exist? $\mathbf{N}(Y$ or $N)$

Severity - 
18. Bridge Type: 1a

1a- Vertical abutments with wingwalls

1 b- Vertical abutments without wingwalls

2- Vertical abutments and wingwalls, sloping embankment Wingwalls perpendicular to abut. face

3- Spill through abutments

4- Sloping embankment, vertical wingwalls and abutments

Wingwall angle less than $90^{\circ}$.

19. Bridge Deck Comments (surface cover variations, measured bridge and span lengths, bridge type variations, approach overflow width, etc.)

4. On the left bank US is TH 41 and a small home on the hillside. The left bank DS surface cover has a few trees, many bushes and a small clearing where tall grass and small bushes are growing.

7. Bridge dimensions are from the VT AOT. The measured bridge length is $23.5 \mathrm{ft}$., bridge span is $21.3 \mathrm{ft}$., and the bridge width is $12.6 \mathrm{ft}$.

\section{Upstream Channel Assessment}

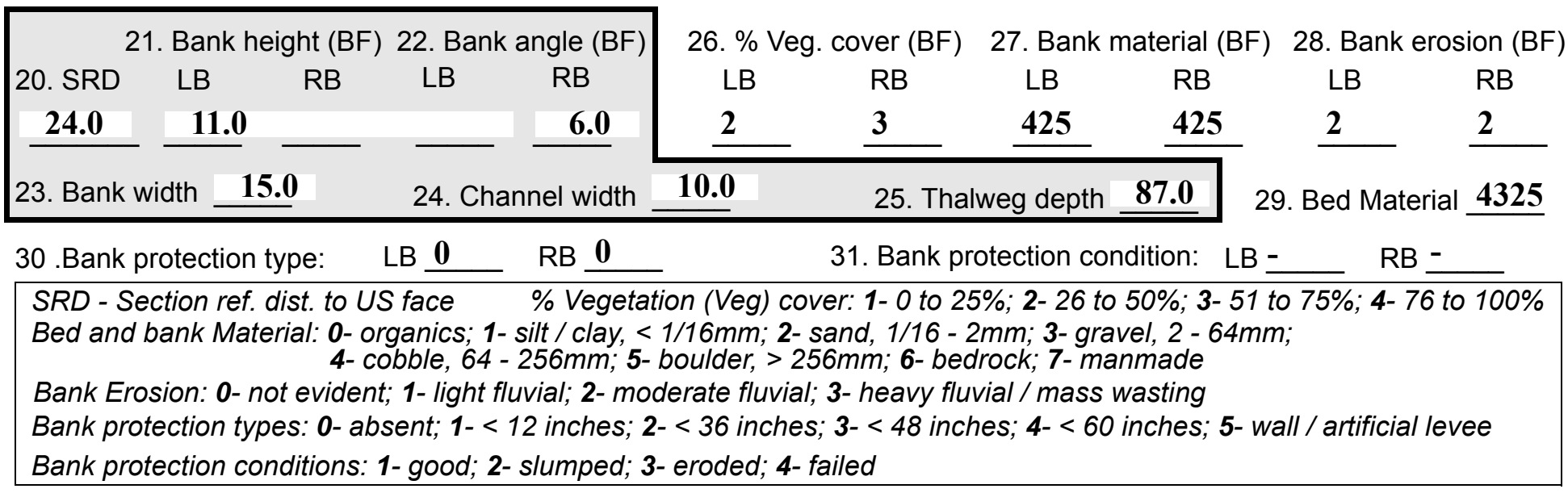

32. Comments (bank material variation, minor inflows, protection extent, etc.):

The channel is straight, however, both banks have eroded extensively which has led to slumping. Vegetation on both banks has fallen down, covering the stream with a canopy of leaves. From $35 \mathrm{ft}$ US to the bridge face, there is an opening in the vegetative canopy. 
33.Point/Side bar present? Y

36. Point bar extent: $\mathbf{3 2}$ feet US

(Y or N. if N type ctrl-n pb)34. Mid-bar distance: 12

35. Mid-bar width: 6

37. Material: 123

38. Point or side bar comments (Circle Point or Side; Note additional bars, material variation, status, etc.):

There is an additional side bar comprised of silt, clay and sand from $3.5 \mathrm{ft}$. US to $3 \mathrm{ft}$. DS. The mid-bar distance is $8 \mathrm{ft}$ under the bridge. At this point the bar is $7 \mathrm{ft}$ wide. The bar is positioned from $50 \% \mathrm{LB}$ to $100 \%$ RB.

39. Is a cut-bank present? $\mathbf{N}$ ( $Y$ or if $N$ type ctrl-n $c b)$

40. Where? (LB or $R B)$

41. Mid-bank distance: -

42. Cut bank extent: feet (US, UB) to feet (US, UB, DS)

43. Bank damage: (1- eroded and/or creep; 2- slip failure; 3- block failure)

44. Cut bank comments (eg. additional cut banks, protection condition, etc.):

There are no cut-banks present.

45. Is channel scour present? $\mathbf{Y}$ ( $Y$ or if $N$ type ctrl-n cs)

47. Scour dimensions: Length $\mathbf{1 8 . 5}$ Width $\mathbf{5}$ Depth : 1

46. Mid-scour distance: $\underline{5}$

48. Scour comments (eg. additional scour areas, local scouring process, etc.):

The scour is deepest at the corner of the US end of the left abutment and the US left wingwall. The thalweg was measured out of the scour hole and is assumed to be $1.1 \mathrm{ft}$. The scour extends from $8.5 \mathrm{ft}$ US to $10 \mathrm{ft}$. under the bridge.

\section{Are there major confluences? $\mathbf{N}$}

51. Confluence 1: Distance Confluence 2: Distance 52. Enters on Enters on 54. Confluence comments (eg. confluence name):

There are no major confluences.
50. How many? -

53. Type(1-perennial; 2- ephemeral) Type (1-perennial; 2- ephemeral) ( $(L B$ or $R B)$ (LB or $R B)$ (1-perennia

(1)

55. Channel restraint (BF)? LB 2

\title{
D. Under Bridge Channel Assessment
}

\begin{tabular}{|c|c|c|c|c|c|c|c|}
\hline \multicolumn{2}{|c|}{ 56. Height (BF) } & \multicolumn{2}{|c|}{57 Angle (BF) } & \multicolumn{2}{|c|}{ 61. Material (BF) } & \multicolumn{2}{|c|}{ 62. Erosion (BF) } \\
\hline LB & $\mathrm{RB}$ & LB & $\mathrm{RB}$ & LB & $\mathrm{RB}$ & LB & $\mathrm{RB}$ \\
\hline 18.0 & & 1.5 & & 2 & 7 & 7 & - \\
\hline
\end{tabular}

63. Bed Material -

Bed and bank Material: 0- organics; 1- silt / clay, < 1/16mm; 2- sand, 1/16 - 2mm; 3- gravel, 2 - 64mm; 4- cobble, 64 - 256mm; 5- boulder, > 256mm; 6- bedrock; 7- manmade

Bank Erosion: 0- not evident; 1- light fluvial; 2- moderate fluvial; 3- heavy fluvial / mass wasting

64. Comments (bank material variation, minor inflows, protection extent, etc.):

1234

63. The right side of the channel bed is silt, clay, sand and gravel from the side bar. The center of the channel is cobble. The left side of the channel is comprised of boulders protecting the DS end of the left abutment. 
65. Debris and Ice Is there debris accumulation?

67. Debris Potential $\underline{3}$ ( 1- Low; 2- Moderate; 3- High)

69. Is there evidence of ice build-up? 2

70. Debris and Ice Comments:

2

65. There is debris caught on both US wingwalls.
$(Y$ or $N)$ 66. Where? $\mathbf{Y}$

68. Capture Efficiency 2

(1- Upstream; 2- At bridge; 3- Both)

Ice Blockage Potential $\mathbf{N}$
(1-Low; 2- Moderate; 3- High)

(1-Low; 2-Moderate; 3- High)

\begin{tabular}{|l|c|c|c|c|c|c|c|c|}
\hline Abutments & $\begin{array}{c}\text { 71. Attack } \\
\angle \text { (BF) }\end{array}$ & $\begin{array}{c}\text { 72. Slope } \angle \\
\text { (Qmax) }\end{array}$ & $\begin{array}{c}\text { 73. Toe } \\
\text { loc. (BF) }\end{array}$ & $\begin{array}{c}\text { 74. Scour } \\
\text { Condition }\end{array}$ & $\begin{array}{c}75 . \text { Scour } \\
\text { depth }\end{array}$ & $\begin{array}{c}\text { 76. Exposure } \\
\text { depth }\end{array}$ & 77. Material & 78. Length \\
\hline LABUT & & $\mathbf{0}$ & $\mathbf{9 0}$ & $\mathbf{2}$ & $\mathbf{3}$ & $\mathbf{0}$ & $\mathbf{2 . 1}$ & $\mathbf{9 0 . 0}$ \\
\hline RABUT & $\mathbf{1}$ & $\mathbf{0}$ & $\mathbf{9 0}$ & & & $\mathbf{2}$ & $\mathbf{2}$ & $\mathbf{2 0 . 5}$ \\
\hline
\end{tabular}

Pushed: $L B$ or RB

Toe Location (Loc.): 0- even, 1- set back, 2- protrudes

Scour cond.: 0- not evident; 1- evident (comment); 2- footing exposed; 3-undermined footing; 4- piling exposed; 5- settled; 6- failed

Materials: 1- Concrete; 2- Stone masonry or drywall; 3- steel or metal; 4- wood

79. Abutment comments (eg. undermined penetration, unusual scour processes, debris, etc.):

0

1.1

1

76. The water depth in front of the left abutment footing is $1.1 \mathrm{ft}$. The entire footing of the left abutment is exposed. The exposure of the footing is more pronounced at the US end where there is no protection.

75. The left abutment footing is undermined. A rod can penetrate $2 \mathrm{ft}$. underneath the footing.

80. Wingwalls:

Exist? Material? Scour Scour Exposure $\begin{aligned} & 81 . \\ & \text { Angle? Length? }\end{aligned}$

USLWW: Condition? depth? depth?
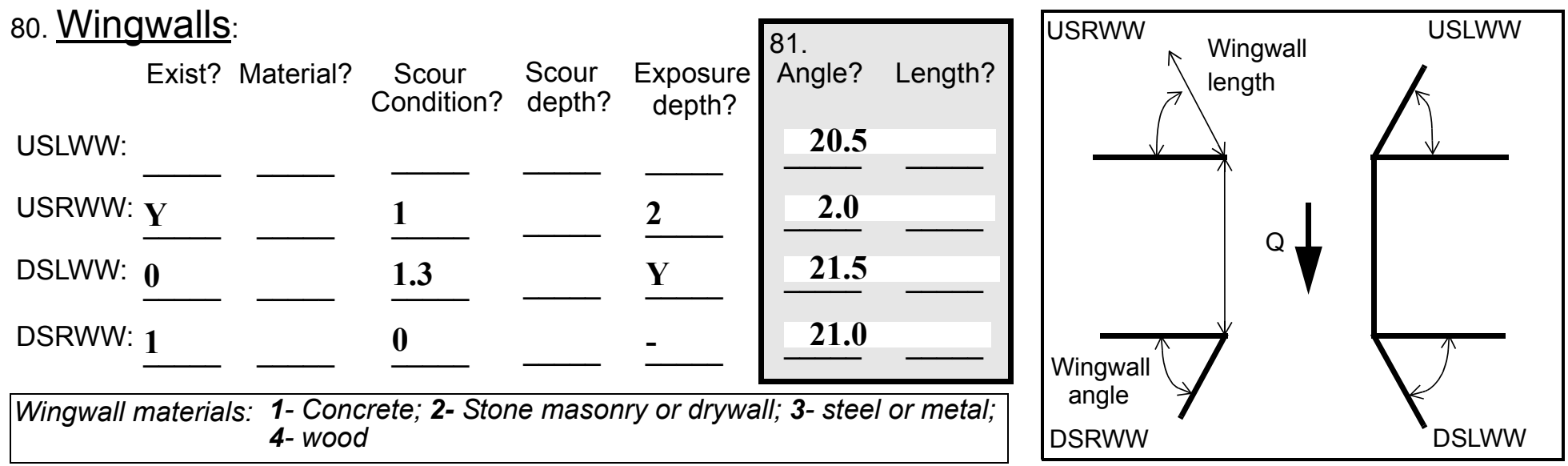

82. Bank / Bridge Protection:

\begin{tabular}{|l|l|l|l|l|l|l|l|l|}
\hline Location & USLWW & USRWW & LABUT & RABUT & LB & RB & DSLWW & DSRWW \\
\hline Type & - & $\mathbf{0}$ & $\mathbf{Y}$ & $\mathbf{0}$ & - & - & $\mathbf{1}$ & - \\
\hline Condition & $\mathbf{Y}$ & - & $\mathbf{1}$ & $\mathbf{0 . 6}$ & - & - & $\mathbf{3}$ & - \\
\hline Extent & $\mathbf{1}$ & - & $\mathbf{2}$ & $\mathbf{0}$ & $\mathbf{0}$ & $\mathbf{2}$ & $\mathbf{0}$ & - \\
\hline
\end{tabular}

Bank / Bridge protection types: 0- absent; 1- < 12 inches; 2- < 36 inches; 3- < 48 inches; 4- < 60 inches; 
83. Wingwall and protection comments (eg. undermined penetration, unusual scour processes, etc.):

-
-
-
-
-
0
-
-
2
1
2

\section{Piers:}

84. Are there piers? $\mathbf{8 0 .}$ ( $Y$ or if $N$ type ctrl-n pr)

\begin{tabular}{|l|l|l|l|l|l|l|l|}
\hline \multirow{2}{*}{$\begin{array}{l}85 . \\
\text { Pier no. }\end{array}$} & \multicolumn{3}{|c|}{ width (w) feet } & \multicolumn{3}{c|}{ elevation (e) feet } \\
\cline { 2 - 8 } & w1 & w2 & w3 & e@w1 & e@w2 & e@w3 \\
\hline Pier 1 & & & & $\mathbf{3 0 . 0}$ & $\mathbf{1 3 . 0}$ & $\mathbf{3 5 . 0}$ \\
\hline Pier 2 & & & & $\mathbf{1 2 . 0}$ & $\mathbf{2 5 . 0}$ & $\mathbf{1 0 . 0}$ \\
\hline Pier 3 & & & - & $\mathbf{2 5 . 0}$ & $\mathbf{1 0 . 0}$ & - \\
\hline Pier 4 & - & - & - & - & - & - \\
Nyyyy
\end{tabular}

\begin{tabular}{|l|l|l|l|l|}
\hline Level 1 Pier Descr. & \multicolumn{1}{|c|}{1} & \multicolumn{1}{|c|}{2} & 3 & \multicolumn{1}{|c|}{} \\
\hline 86. Location (BF) & The & sed. & & - \\
\hline 87. Type & DS & The & & - \\
\hline 88. Material & end & US & & - \\
\hline 89. Shape & of & end & & - \\
\hline 90. Inclined? & the & is in & & - \\
\hline 91. Attack $\angle$ (BF) & US & the & & - \\
\hline 92. Pushed & left & bank & N & - \\
\hline 93. Length (feet) & - & - & - & - \\
\hline 94. \# of piles & wing & - & - & - \\
\hline 95. Cross-members & wall & & - & - \\
\hline 96. Scour Condition & foot- & & - & - \\
\hline 97. Scour depth & ing is & & - & - \\
\hline 98. Exposure depth & expo & & - & - \\
\hline
\end{tabular}

LFP, LTB, LB, MCL, MCM, MCR, RB, RTB, RFP

1- Solid pier, 2- column, 3- bent

1-Wood; 2- concrete; 3- metal; 4- stone

1- Round; 2- Square; 3- Pointed

Y-yes; $N-$ no

$L B$ or $R B$

0- none; 1- laterals; 2- diagonals; 3- both

0- not evident; 1- evident (comment);

2- footing exposed; 3- piling exposed;

4- undermined footing; 5 - settled; $\mathbf{6}$ - failed 
99. Pier comments (eg. undermined penetration, protection and protection extent, unusual scour processes, etc.):

-
-
-
-
-
-
-
-
-
-

100.

\section{E. Downstream Channel Assessment}

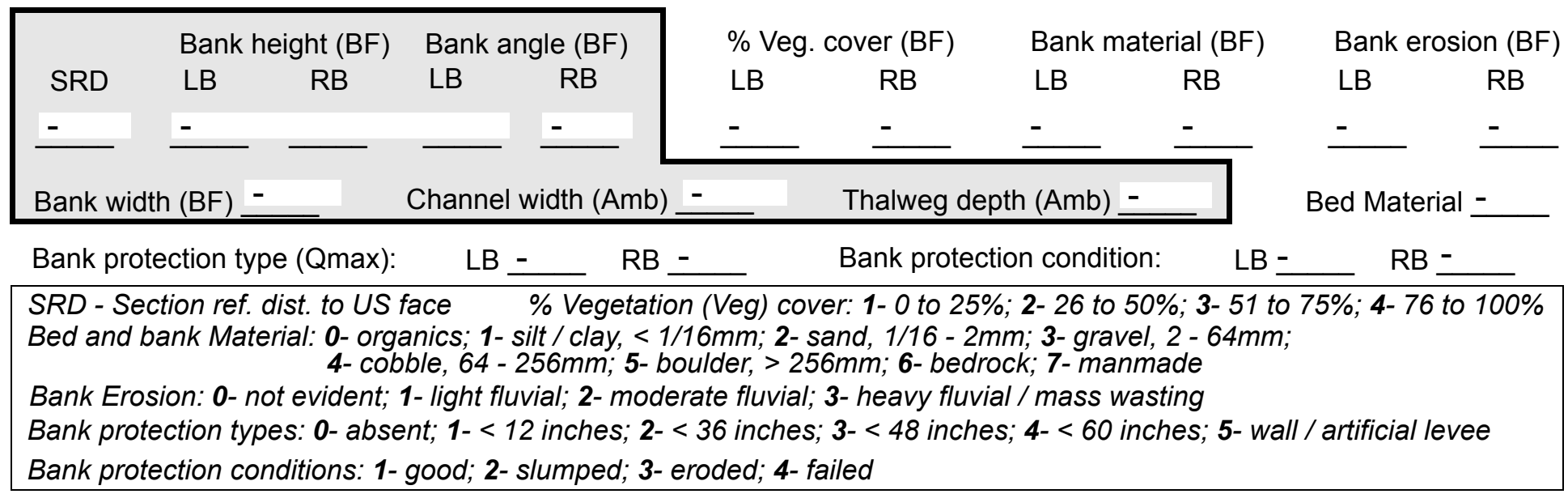

Comments (eg. bank material variation, minor inflows, protection extent, etc.):

-

There are no piers.

101. Is a drop structure present? ___ ( or $N$, if $N$ type ctrl-n ds) 102. Distance: ___ feet
103. Drop: - feet
104. Structure material:
(1- steel sheet pile; 2- wood pile; 3- concrete; 4- other)

105. Drop structure comments (eg. downstream scour depth): 
106. Point/Side bar present? $\underline{\mathbf{2 3}}$ (Y or N. if N type ctrl-n pb)Mid-bar distance: $\underline{4}$ Mid-bar width: 2

Point bar extent: 2 feet $\underline{234}$ (US, UB, DS) to $\underline{5}$ feet $\mathbf{0}$ (US, UB, DS) positioned $\underline{\mathbf{0}}$ $\%$ LB to $\% \mathrm{RB}$

Material:

Point or side bar comments (Circle Point or Side; note additional bars, material variation, status, etc.):

There is a log holding up the bank from $12 \mathrm{ft}$ DS to $36 \mathrm{ft}$ DS. The log was protecting the bank from erosion as of $08 / 07 / 96$.

Is a cut-bank present? (Y or if $N$ type ctrl-n cb) Where? (LB or $R B)$

Mid-bank distance:

Cut bank extent: feet (US, UB, DS) to feet (US, UB, DS)

Bank damage: (1- eroded and/or creep; 2- slip failure; 3- block failure)

Cut bank comments (eg. additional cut banks, protection condition, etc.):

$\mathbf{N}$

Is channel scour present? - (Y or if $N$ type ctrl-n cs) Mid-scour distance: Ther

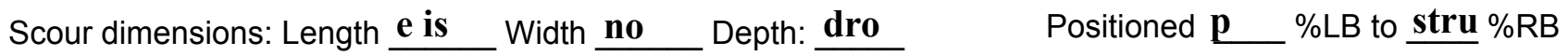
Scour comments (eg. additional scour areas, local scouring process, etc.): cture at the site.

Are there major confluences? ( $Y$ or if $N$ type ctrl-n $m c)$

How many?

Confluence 1: Distance $\underline{\mathbf{Y}}$ Enters on 27 (LB or RB)

Type $\underline{6.5}$ (1- perennial; 2- ephemeral) Confluence 2: Distance $\mathbf{2 0}$ Enters on $\underline{\text { DS }}(L B$ or $R B)$ Type 33.4 (1- perennial; 2- ephemeral) Confluence comments (eg. confluence name):

DS

0

\section{F. Geomorphic Channel Assessment}

107. Stage of reach evolution $\mathbf{2 5}$

1- Constructed

2- Stable

3- Aggraded

4- Degraded

5- Laterally unstable

6- Vertically and laterally unstable 
108. Evolution comments (Channel evolution not considering bridge effects; See HEC-20, Figure 1 for geomorphic descriptors):

325

$\mathbf{N}$

$-$

$-$

$-$

$-$ 


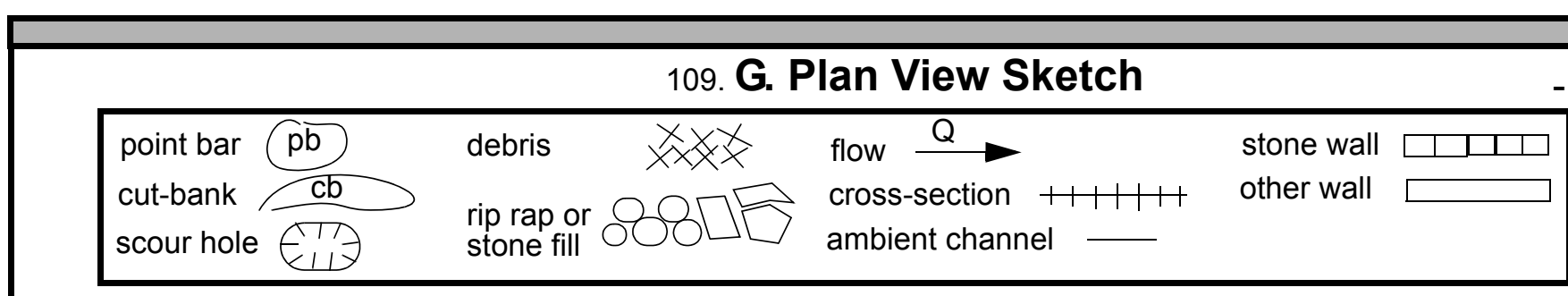

cut-bank $\mathrm{cb}$

scour hole rip rap or
stone fill stone fill cross-section $+1+1+1$ ambient channe other wall 
APPENDIX F:

SCOUR COMPUTATIONS 


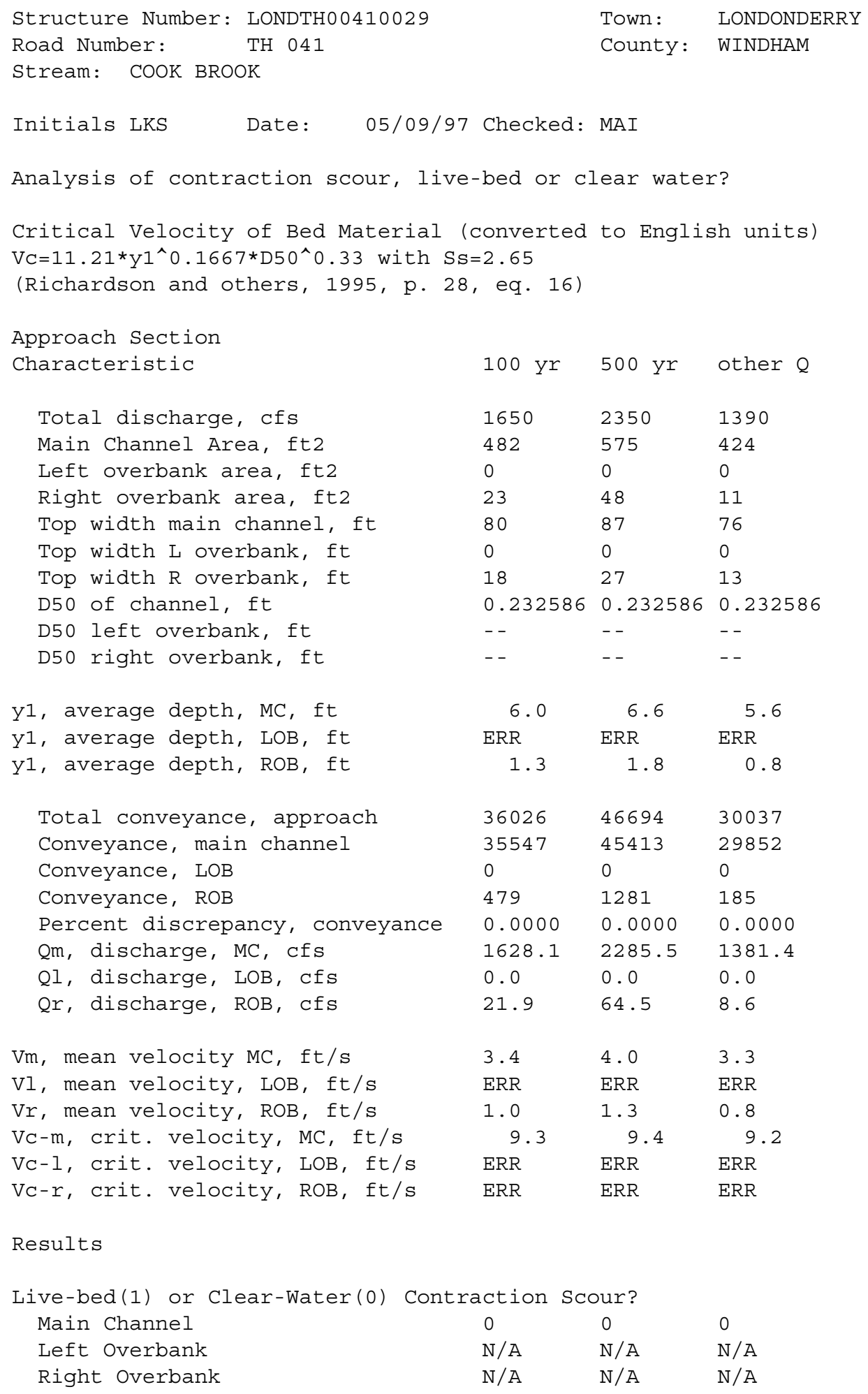

\begin{tabular}{|c|c|c|}
\hline $100 \mathrm{yr}$ & $500 \mathrm{yr}$ & other $Q$ \\
\hline 1650 & 2350 & 1390 \\
\hline 482 & 575 & 424 \\
\hline 0 & 0 & 0 \\
\hline 23 & 48 & 11 \\
\hline 80 & 87 & 76 \\
\hline 0 & 0 & 0 \\
\hline 18 & 27 & 13 \\
\hline 0.232586 & 0.232586 & 0.232586 \\
\hline-- & -- & -- \\
\hline - - & -- & -- \\
\hline 6.0 & 6.6 & 5.6 \\
\hline ERR & ERR & ERR \\
\hline 1.3 & 1.8 & 0.8 \\
\hline 36026 & 46694 & 30037 \\
\hline 35547 & 45413 & 29852 \\
\hline 0 & 0 & 0 \\
\hline 479 & 1281 & 185 \\
\hline 0.0000 & 0.0000 & 0.0000 \\
\hline 1628.1 & 2285.5 & 1381.4 \\
\hline 0.0 & 0.0 & 0.0 \\
\hline 21.9 & 64.5 & 8.6 \\
\hline 3.4 & 4.0 & 3.3 \\
\hline ERR & $\mathrm{ERR}$ & ERR \\
\hline 1.0 & 1.3 & 0.8 \\
\hline 9.3 & 9.4 & 9.2 \\
\hline ERR & ERR & ERR \\
\hline ERR & ERR & ERR \\
\hline \multicolumn{3}{|c|}{ action Scour? } \\
\hline 0 & 0 & 0 \\
\hline $\mathrm{N} / \mathrm{A}$ & $\mathrm{N} / \mathrm{A}$ & $\mathrm{N} / \mathrm{A}$ \\
\hline $\mathrm{N} / \mathrm{A}$ & $\mathrm{N} / \mathrm{A}$ & $\mathrm{N} / \mathrm{A}$ \\
\hline
\end{tabular}


Clear water Contraction Scour in MAIN CHANNEL

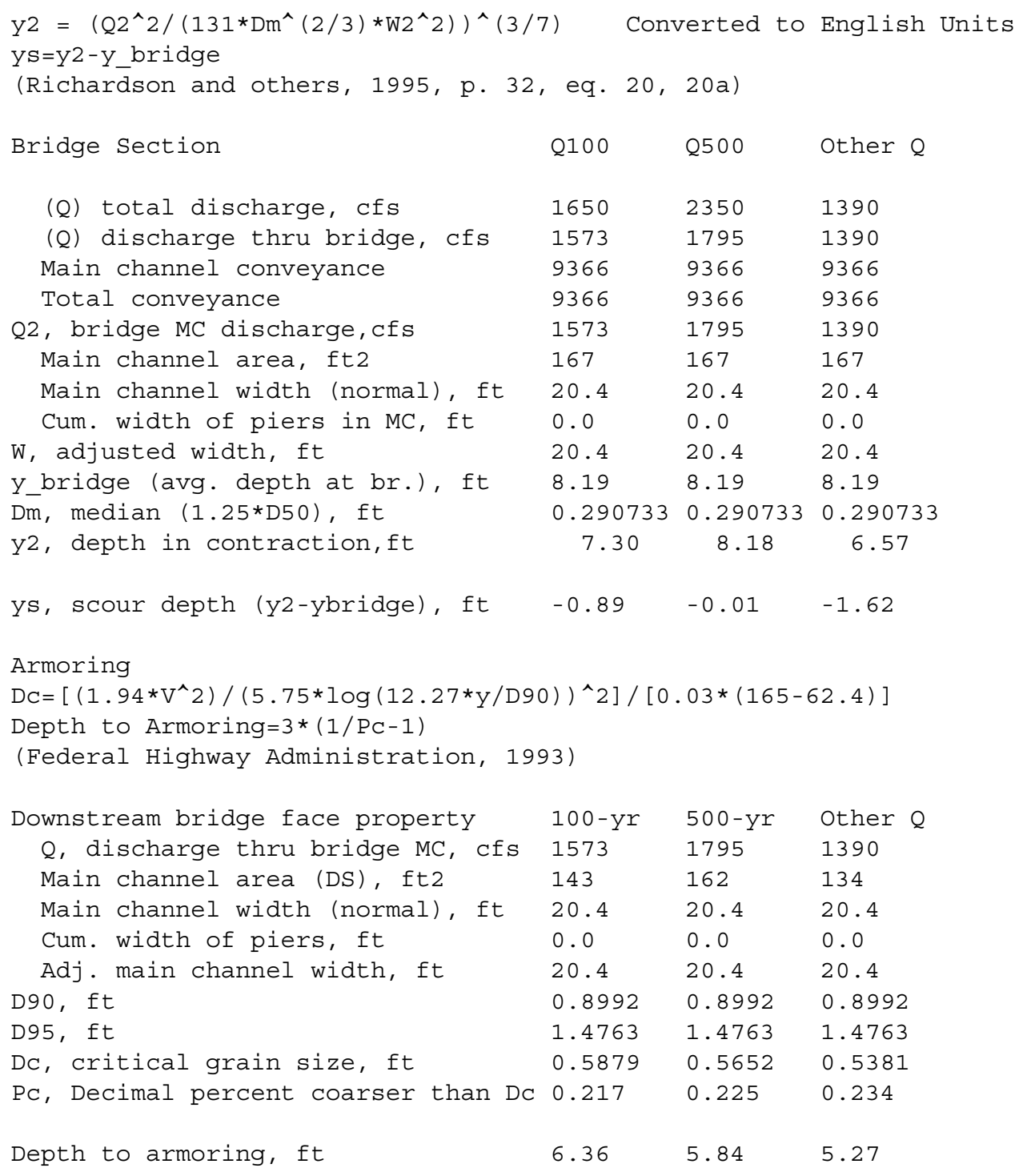




\begin{tabular}{|c|c|c|c|c|}
\hline $\begin{array}{l}\text { Chang pressure flow equation } \\
\text { Cq=1/Cf*CC Cf=1.5*Fr^0.43 (<=1) } \\
\text { Umbrell pressure flow equation } \\
(\mathrm{Hb}+\mathrm{Ys}) / \mathrm{Ya}=1.1021 *[(1-\mathrm{w} / \mathrm{Ya}) *(\mathrm{Va} / \mathrm{VC})] \\
\text { (Richardson and other, } 1995, \mathrm{p} .144\end{array}$ & $\begin{array}{l}\mathrm{Hb}+\mathrm{Ys}=\mathrm{Cq} \\
\mathrm{CC}=\mathrm{SQRT}[0 \\
]^{\wedge} 0.6031 \\
-146)\end{array}$ & $\begin{array}{l}{ }^{*} \mathrm{qbr} / \mathrm{Vc} \\
0.10(\mathrm{Hb} /(\end{array}$ & $(y a-w)-0.56)]+0.79$ & $(<=1)$ \\
\hline & Q100 & Q500 & OtherQ & \\
\hline Q, total, cfs & 1650 & 2350 & 1390 & \\
\hline Q, thru bridge $M C$, cfs & 1573 & 1795 & 1390 & \\
\hline Vc, critical velocity, ft/s & 9.30 & 9.44 & 9.18 & \\
\hline Va, velocity MC approach, ft/s & 3.38 & 3.97 & 3.26 & \\
\hline Main channel width (normal), ft & 20.4 & 20.4 & 20.4 & \\
\hline Cum. width of piers in MC, ft & 0.0 & 0.0 & 0.0 & \\
\hline W, adjusted width, ft & 20.4 & 20.4 & 20.4 & \\
\hline qbr, unit discharge, ft2/s & 77.1 & 88.0 & 68.1 & \\
\hline Area of full opening, ft2 & 167.0 & 167.0 & 167.0 & \\
\hline $\mathrm{Hb}$, depth of full opening, ft & 8.19 & 8.19 & 8.19 & \\
\hline Fr, Froude number, bridge MC & 0.58 & 0.66 & 0.51 & \\
\hline Cf, Fr correction factor $(<=1.0)$ & 1.00 & 1.00 & 1.00 & \\
\hline **Area at downstream face, ft2 & 143 & 162 & 134 & \\
\hline **Hb, depth at downstream face, ft & 7.01 & 7.94 & 6.57 & \\
\hline **Fr, Froude number at DS face & 0.73 & 0.69 & 0.71 & \\
\hline$* * \mathrm{Cf}$, for downstream face $(<=1.0)$ & 1.00 & 1.00 & 1.00 & \\
\hline Elevation of Low steel, ft & 498.35 & 498.35 & 498.35 & \\
\hline Elevation of Bed, ft & 490.16 & 490.16 & 490.16 & \\
\hline Elevation of Approach, ft & 500.59 & 501.71 & 499.85 & \\
\hline Friction loss, approach, ft & 0.12 & 0.15 & 0.1 & \\
\hline Elevation of WS immediately US, ft & 500.47 & 501.56 & 499.75 & \\
\hline ya, depth immediately US, ft & 10.31 & 11.40 & 9.59 & \\
\hline Mean elevation of deck, ft & 499.87 & 499.87 & 499.87 & \\
\hline w, depth of overflow, ft $(>=0)$ & 0.60 & 1.69 & 0.00 & \\
\hline Cc, vert contrac correction $(<=1.0)$ & 0.96 & 0.96 & 0.96 & \\
\hline$* * C \mathrm{C}$, for downstream face $(<=1.0)$ & 0.917355 & 0.95067 & 0.901898 & \\
\hline Ys, scour w/Chang equation, ft & 0.47 & 1.54 & -0.47 & \\
\hline Ys, scour w/Umbrell equation, ft & -2.24 & -1.42 & -2.53 & \\
\hline
\end{tabular}


**Ys, scour w/Umbrell equation, ft $-1.06 \quad-1.18 \quad-0.91$

In UNsubmerged orifice flow, an adjusted scour depth using the Laursen equation results and the estimated downstream bridge face properties can also be computed (ys=y2-ybridgeDs)

$\begin{array}{lllll}\text { Y2, from Laursen's equation, ft } & 7.30 & 8.18 & 6.57 \\ \text { WSEL at downstream face, ft } & 497.17 & 498.10 & 496.75 \\ \text { Depth at downstream face, ft } & 7.01 & 7.94 & 6.57\end{array}$

Ys, depth of scour (Laursen), ft $0.29 \quad 0.23 \quad 0.00$

Abutment scour

Froehlich's Abutment Scour

$\mathrm{Ys} / \mathrm{Y} 1=2.27 * \mathrm{~K} 1 * \mathrm{~K} 2 *\left(\mathrm{a}^{\prime} / \mathrm{Y} 1\right)^{\wedge} 0.43 * \mathrm{Fr} 1^{\wedge} 0.61+1$

(Richardson and others, 1995, p. 48, eq. 28)

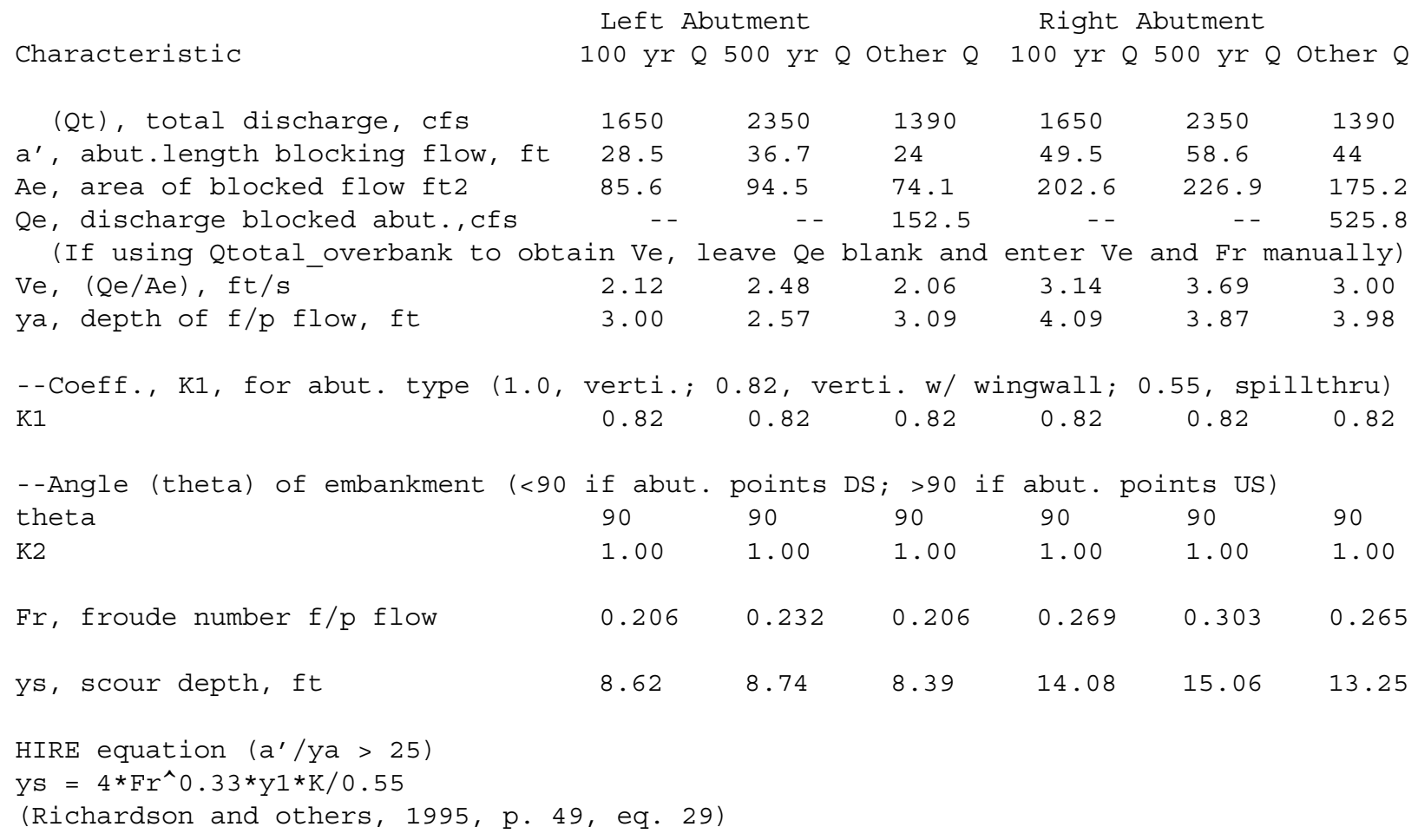




\begin{tabular}{|c|c|c|c|c|c|c|}
\hline$a^{\prime}$ (abut length blocked, ft) & 28.5 & 36.7 & 24 & 49.5 & 58.6 & 44 \\
\hline y1 (depth f/p flow, ft) & 3.00 & 2.57 & 3.09 & 4.09 & 3.87 & 3.98 \\
\hline$a^{\prime} / y^{\prime}$ & 9.49 & 14.25 & 7.77 & 12.09 & 15.13 & 11.05 \\
\hline Skew correction (p. 49, fig. 16) & 1.00 & 1.00 & 1.00 & 1.00 & 1.00 & 1.00 \\
\hline Froude no. f $/ p$ flow & 0.21 & 0.23 & 0.21 & 0.27 & 0.30 & 0.27 \\
\hline Ys w/ corr. factor $\mathrm{K} 1 / 0.55$ : & $E R R$ & FRR & $E R R$ & $E R R$ & $E R R$ & ERR \\
\hline vertical w/ $\mathrm{ww}^{\prime} \mathrm{s}$ & ERR & $\mathrm{ERR}$ & $\mathrm{ERR}$ & $\mathrm{ERR}$ & $\mathrm{ERR}$ & ERR \\
\hline spill-through & ERR & ERR & ERR & ERR & ERR & ERR \\
\hline Abutment riprap Sizing & & & & & & \\
\hline Isbash Relationship & & & & & & \\
\hline $\begin{array}{l}\mathrm{D} 50=\mathrm{Y}^{*} \mathrm{~K} * \mathrm{Fr} \mathrm{r}^{\wedge} /(\mathrm{Ss}-1) \text { and } \mathrm{D} 50=\mathrm{Y} * \mathrm{~K} * \\
\text { (Richardson and others, 1995, p11 }\end{array}$ & $\begin{array}{l}\wedge \\
2) \wedge 0 \\
\text { eq. }\end{array}$ & ( $S s-1)$ & & & & \\
\hline Downstream bridge face property & Q100 & Q500 & Other $\mathrm{Q}$ & Q100 & Q500 & Other $Q$ \\
\hline Fr, Froude Number & 0.73 & 0.69 & 0.71 & 0.73 & 0.69 & 0.71 \\
\hline$y$, depth of flow in bridge, ft & 7.01 & 7.94 & 6.57 & 7.01 & 7.94 & 6.57 \\
\hline Median stone Diameter for riprap & : left & utment & & right & abutment, & ft \\
\hline Fr<=0.8 (vertical abut.) & 2.31 & 2.34 & 2.05 & 2.31 & 2.34 & 2.05 \\
\hline Fr>0.8 (vertical abut.) & $\mathrm{ERR}$ & $\mathrm{ERR}$ & $\mathrm{ERR}$ & ERR & ERR & ERR \\
\hline Fr<=0.8 (spillthrough abut.) & 2.01 & 2.04 & 1.79 & 2.01 & 2.04 & 1.79 \\
\hline Fr>0.8 (spillthrough abut.) & $\mathrm{ERR}$ & ERR & $\mathrm{ERR}$ & $\mathrm{ERR}$ & $\mathrm{ERR}$ & ERR \\
\hline
\end{tabular}

